OPEN ACCESS

Edited by:

Tony D. James,

University of Bath, United Kingdom

Reviewed by:

Valeria Amendola,

University of Pavia, Italy

Philip A. Gale,

University of Sydney, Australia

*Correspondence:

Robert B. P. Elmes

robert.elmes@mu.ie

Specialty section:

This article was submitted to

Supramolecular Chemistry,

a section of the journal

Frontiers in Chemistry

Received: 15 February 2019 Accepted: 29 April 2019

Published: 22 May 2019

Citation:

Kumawat LK, Abogunrin AA, Kickham M, Pardeshi J, Fenelon O,

Schroeder M and Elmes RBP (2019)

Squaramide-Naphthalimide Conjugates as "Turn-On" Fluorescent

Sensors for Bromide Through an

Aggregation-Disaggregation

Approach. Front. Chem. 7:354.

doi: 10.3389/fchem.2019.00354

\section{Squaramide-Naphthalimide Conjugates as "Turn-On" Fluorescent Sensors for Bromide Through an Aggregation-Disaggregation Approach}

\author{
Lokesh K. Kumawat ${ }^{1}$, Anthony A. Abogunrin ${ }^{1}$, Michelle Kickham ${ }^{1,2}$, Jyotsna Pardeshi ${ }^{2}$, \\ Orla Fenelon ${ }^{1}$, Martina Schroeder ${ }^{2,3}$ and Robert B. P. Elmes ${ }^{1,3 *}$ \\ ${ }^{1}$ Department of Chemistry, Maynooth University, National University of Ireland, Maynooth, Ireland, ${ }^{2}$ Department of Biology, \\ Maynooth University, National University of Ireland, Maynooth, Ireland, ${ }^{3}$ Maynooth University Human Health Research \\ Institute, Maynooth University, National University of Ireland, Maynooth, Ireland
}

The syntheses of two new squaramide-naphthalimide conjugates (SQ1 and SQ2) are reported where both compounds have been shown to act as selective fluorescence "turn on" probes for bromide in aqueous DMSO solution through a disaggregation induced response. SQ1 and SQ2 displayed a large degree of self-aggregation in aqueous solution that is disrupted at increased temperature as studied by ${ }^{1} \mathrm{H}$ NMR and Scanning Electron Microscopy (SEM). Moreover, the fluorescence behavior of both receptors was shown to be highly dependent upon the aggregation state and increasing temperature gave rise to a significant increase in fluorescence intensity. Moreover, this disaggregation induced emission (DIE) response was exploited for the selective recognition of certain halides, where the receptors gave rise to distinct responses related to the interaction of the various halide anions with the receptors. Addition of $\mathrm{F}^{-}$rendered both compounds non-emissive; thought to be due to a deprotonation event while, surprisingly, $\mathrm{Br}^{-}$resulted in a dramatic 500-600\% fluorescence enhancement thought to be due to a disruption of compound aggregation and allowing the monomeric receptors to dominate in solution. Furthermore, optical sensing parameters such as limits of detection and binding constant of probes were also measured toward the various halides $\left(\mathrm{F}^{-}, \mathrm{Cl}^{-}, \mathrm{Br}^{-}\right.$, and $\left.\mathrm{I}^{-}\right)$where both $\mathbf{S Q 1}$ and SQ2 were found to sense halides with adequate sensitivity to measure $\mu \mathrm{M}$ levels of halide contamination. Finally, initial studies in a human cell line were also conducted where it was observed that both compounds are capable of being taken up by HeLa cells, exhibiting intracellular fluorescence as measured by both confocal microscopy and flow cytometry. Finally, using flow cytometry we were also able to show that cells treated with $\mathrm{NaBr}$ exhibited a demonstrable spectroscopic response when treated with either SQ1 or SQ2.

Keywords: supramolecular chemistry, squaramide, 1, 8-naphthalimide, fluorescent sensor, anion recognition 


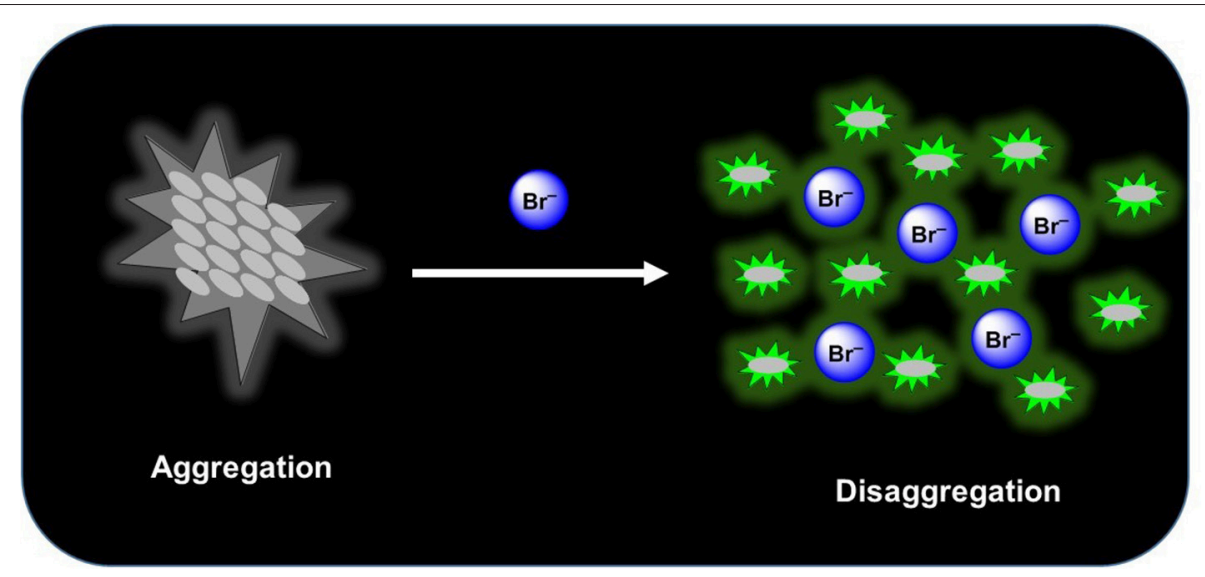

\section{INTRODUCTION}

Anion sensing has been a key area of supramolecular chemistry since the introduction of the field in the early 1970's (Beer and Gale, 2001; Gunnlaugsson et al., 2006; Duke et al., 2010; Busschaert et al., 2015; Gale et al., 2016; Langton et al., 2016). In particular the recognition and sensing of halides has garnered considerable research interest due to their prevalence in biological and ecological settings (Verkman, 1990; Cametti and Rissanen, 2009, 2013; Evans and Beer, 2014; Ashton et al., 2015). While chloride and fluoride have captivated much of the research interest due to their major roles in cellular homeostasis, acid/base equilibria, and pollution concerns other halides such as bromide have been largely ignored. This is surprising given the clinical symptoms of bromide intoxication (also known as bromism), a once common disease where large doses of bromide were found to impair neuronal transmission and cause nausea and vomiting, abdominal pain, coma, and paralysis (Olson and System, 2004). Although now rare, bromism cases continue to be reported due to non-prescription bromide-based medications being available over the counter where a recent case resulted in extremely high levels of bromide intoxication (serum bromide level of $1,717 \mathrm{mg} / \mathrm{L}$ ) (Hoizey et al., 2003). Moreover, from an environmental standpoint, bromide pollution can result in reaction between chlorine and naturally occurring organic matter in drinking-water, forming brominated, and mixed chloro-bromo by products such as trihalomethanes or halogenated acetic acids (Gribble, 2004). Indeed, the World Health Organization reports that while low levels of bromide pollution do not seem to have detrimental effects on humans or animals (World Health Organization, 2009), bromate (formed in water during ozonation) is a known carcinogen (World Health Organization, 2005). However, the selective binding and sensing of bromide is made challenging by its intermediate size and hydration energy between chloride and iodide (Marcus, 1991), and reported examples in the literature remain scarce (Kang and Kim, 2005; Suksai et al., 2005; Vlascici et al., 2018). One of the few examples, reported by Qian and co-workers, developed a rhodamine based fluorescent probe capable of selective sensing of iodide and bromide in aqueous solution based on a metal ion removal and anion ligand exchange mechanism (Xu et al., 2012). Nyokong and co-workers reported the use of GSH-capped quantum dots (QDs) covalently linked to a nickel tetraaminophthalocyanine complex where the covalent binding of the QDs to the Ni complex induced fluorescence quenching before with introduction of $\mathrm{Br}$ - restoring the fluorescence (Adegoke and Nyokong, 2013). Most recently, Beer and co-workers developed a redox-active ferrocene functionalized rotaxane with a halogen bonding anion binding site that was capable of selective $\mathrm{Br}^{-}$ sensing over $\mathrm{Cl}^{-}$in the presence of water as measured by ${ }^{1} \mathrm{H}$ NMR and electrochemical measurements (Lim and Beer, 2019).

Much of the literature surrounding anion sensors relies on a binding event that disrupts/enhances some type of electron transfer mechanism such as photoinduced electron transfer (PET), internal charge transfer (ICT), excited state intramolecular proton transfer (ESIPT), fluorescence resonance energy transfer (FRET), etc. to yield a measurable fluorescence response (de Silva et al., 1997; Wu et al., 2011; Fan et al., 2013; Lee et al., 2015; Kumawat et al., 2017; Sedgwick et al., 2018). Some more recent reports take advantage of aggregation induced emission (AIE) (Hong et al., 2011), whereby recognition of an anion causes aggregation of the sensor thereby reducing molecular rotation and inducing large fluorescence perturbations (Peng et al., 2009; Ma et al., 2019). The opposite sensing mechanism, disaggregation induced emission (DIE), where disassembly of a non-fluorescent aggregate releases individual fluorescent molecules has received much less attention even though the process from aggregation to disaggregation generally causes a recovery or enhancement of fluorescence signals, and thus provides a useful method to design "turn-on" probes (Zhai et al., 2014). Recognition events that induce a fluorescence increase are preferable from the perspective of industrial/medical application where such a facile "turn-on" response can give naked-eye real-time information. Indeed, a recent report from O'Shea and co-workers detailed the use of an amphiphilic $\mathrm{BF}_{2}$-azadipyrromethene (NIR-AZA) DIE probe 

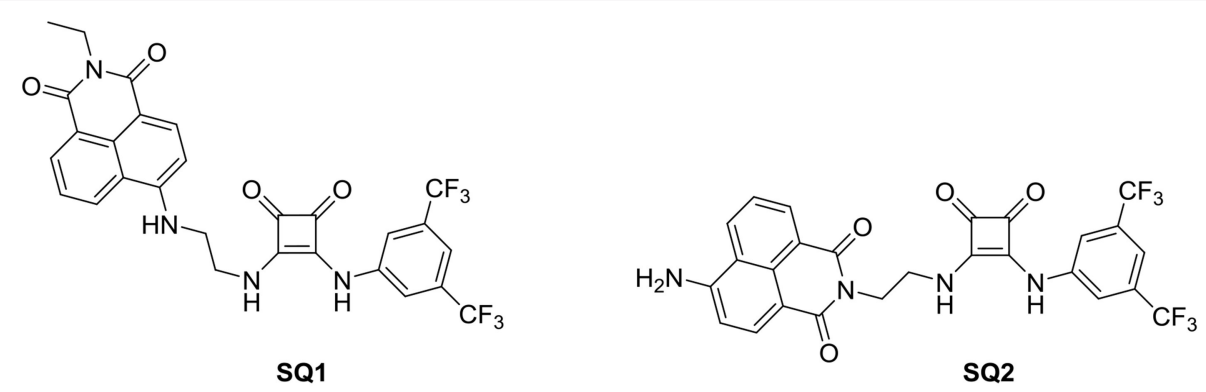

FIGURE 1 | Chemical structures of probes SQ1 and SQ2.

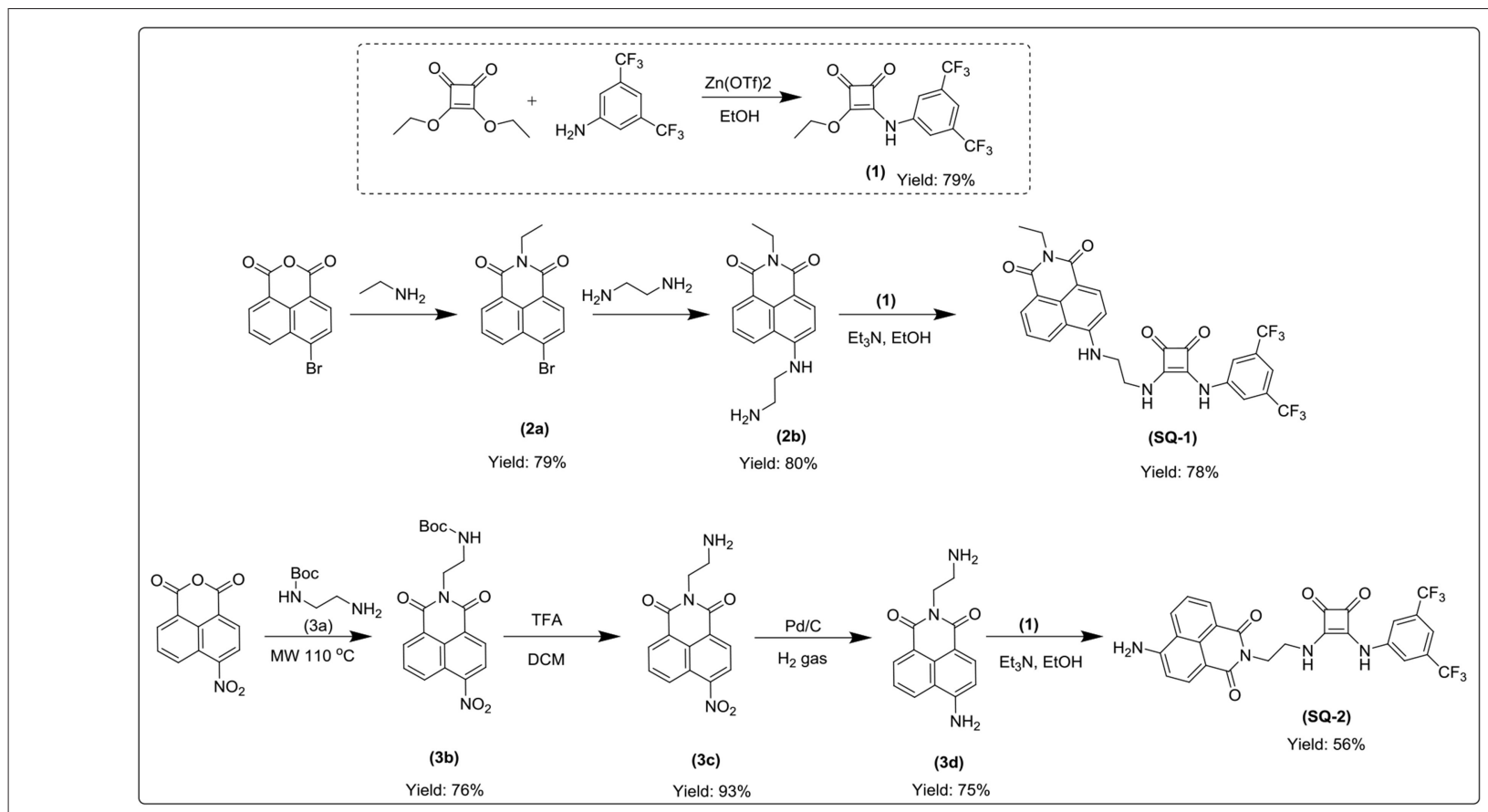

SCHEME 1 | Syntheses of SQ1 and SQ2.

where a membrane selective fluorescence "off to on" switching event allowed visualization of dynamic cellular events in realtime (Wu et al., 2018). Here the authors exemplify how DIE can be exploited to produce a signal in response to a biological event specific to the plasma membrane, allowing real-time visualization of cell-cell contacts through pairs of filopodia.

From our work on squaramides we are familiar with the self-assembly/aggregation of these molecules due to bidirectional $\mathrm{H}$-bonding interactions in addition to $\pi-\pi$ stacking brought about by the aromatic cyclobutenedione ring (Elmes et al., 2013, 2014, 2015; Busschaert et al., 2014; Elmes and Jolliffe, 2014; Qin et al., 2016; Marchetti et al., 2018). Moreover, we have also gained considerable experience working with the naphthalimide fluorophore which has fluorescence properties that are highly dependent upon aggregation (Elmes and Gunnlaugsson, 2010; Elmes et al., 2012; Ryan et al., 2012, 2015; Ao et al., 2017). Indeed, Scanlan, Gunnlaugsson and co-workers have recently shown glycosylated naphthalimide and naphthalimide Tröger's bases that act as fluorescent aggregation probes for the Con A protein where both structures self-assemble in solution to form supramolecular structures by head-to-tail $\pi-\pi$ stacking and extended hydrogen bonding interactions (Calatrava-Pérez et al., 2019). Inspired by this work, we envisaged that a naphthalidesquaramide conjugate may also aggregate efficiently in solution and such aggregation behavior may be modulated upon anion recognition where a disruption of a $\mathrm{H}$-bonding network would reverse self-assembly. Thus, we set about designing a small family of squaramide-naphthalimide conjugates in which we wished to vary the position of the squaramide in relation to the naphthalimide to place the squaramide at either the "head" or the "tail" of the structure (Figure 1). As shown in Scheme 1 our design incorporated a short linker with a significantly hydrophobic side arm that we expected may aid in the aggregation behavior of the sensors in polar solvents.

Herein, we report the synthesis of compounds SQ1 and SQ2 where we have exploited their aggregation behavior and found 


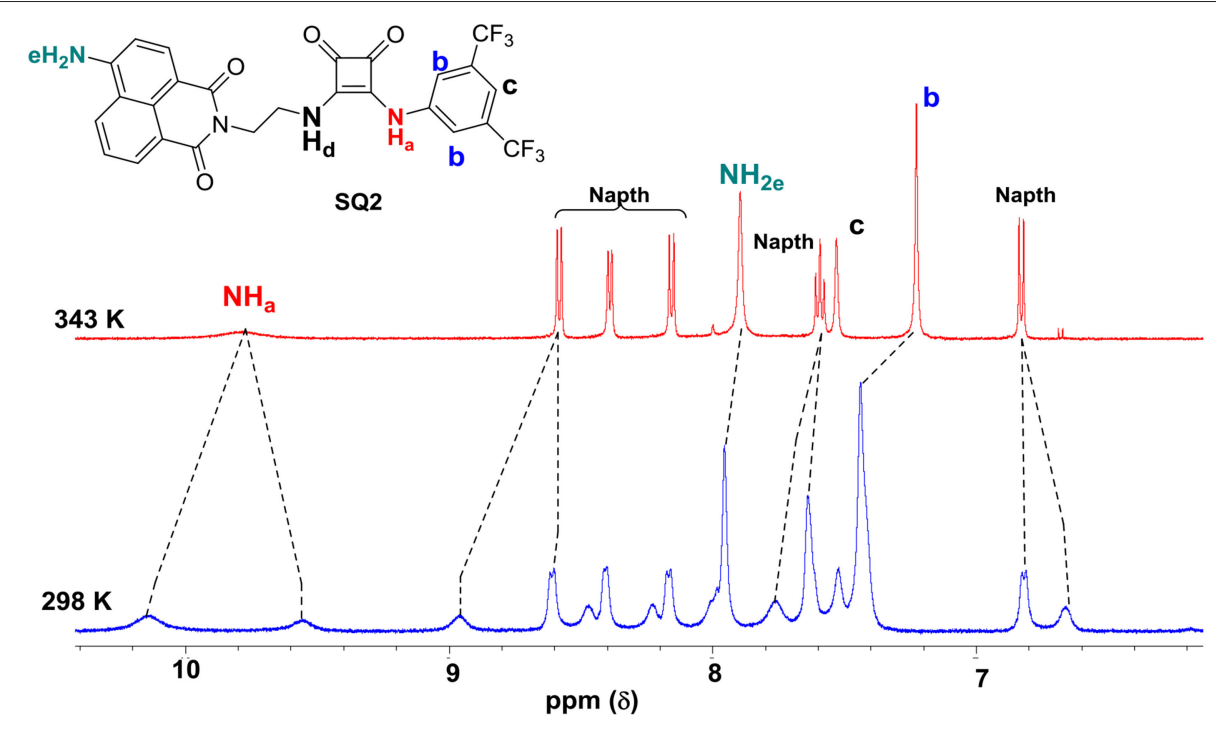

FIGURE 2 | Disaggregation response of probes SQ2 $\left(5.0 \times 10^{-3} \mathrm{M}\right)$ at different temperatures. in DMSO-d 6 .

differing fluorescence responses to various halides in solution. We have discovered that both SQ1 and SQ2 behave as DIE based sensors in solution show differing responses to various anions but with an unexpectedly selective fluorescence "turn on" response to bromide. Moreover, initial results obtained with the HeLa cell line demonstrate that the effect can also be observed in the complex biological environment of a human cell.

\section{RESULTS AND DISCUSSIONS}

\section{Synthesis}

The syntheses of compounds SQ1 and SQ2 were achieved using the synthetic pathway outlined in Scheme 1. Briefly, SQ1 was synthesized by amination of 4-bromo-1,8-naphthalimide 2a using ethylenediamine before nucleophilic addition of the resulting intermediate $\mathbf{2} \mathbf{b}$ to 3,5 -bis(trifluoromethyl)phenyl squarate monoester $\mathbf{1}$ to yield SQ1 in 78\% yield. Similarly, SQ2 was formed from an initial reaction of 4-nitro-1,8naphthalic anhydride $\mathbf{3}$ with $N$-Boc-ethylenediamine $\mathbf{3 a}$ to yield intermediate $\mathbf{3} \mathbf{b}$ before subsequent TFA mediated deprotection of the Boc group $3 \mathrm{c}$ and catalytic reduction of the nitro group yielded compound $\mathbf{3 d}$ that was also reacted with 3,5-bis(trifluoromethyl)phenyl squarate monoester $\mathbf{1}$ to yield SQ2 in 56\% yield. All compounds and intermediates were fully characterized by ${ }^{1} \mathrm{H}$ NMR, ${ }^{13} \mathrm{C}$ NMR, HRMS and IR spectroscopy (see Supporting Information). However, during NMR characterization it was noted that the ${ }^{1} \mathrm{H}$ NMR spectra of both SQ1 and SQ2 gave rise to complex spectra exhibiting significantly broadened peaks. Indeed, as discussed above, it is well-known that squaramides benefit from several characteristics that make them amenable for use in self-assembled materials, in particular their structural rigidity, aromaticity and ability to form strong two-dimensional hydrogen bonds (Storer et al., 2011; Wurm and Klok, 2013). Similarly, naphthalimides, with their extended planar, aromatic structure are well known to partake in $\pi-\pi$ stacking; a characteristic that renders the photophysical properties of napthalimides sensitive to such stacking events (Duke et al., 2010; Banerjee et al., 2013). In order to investigate the self-assembly behavior of SQ1 and SQ2 several techniques such as ${ }^{1} \mathrm{H}$ NMR, fluorescence measurements and SEM were utilized.

\section{Aggregation Behavior Measured by ${ }^{1} \mathrm{H}$ NMR and SEM Spectroscopy}

The ${ }^{1} \mathrm{H}$ NMR spectra of SQ1 and SQ2 in d6-DMSO was measured at both 298 and $343 \mathrm{~K}$. Both spectra clearly showed substantial differences between room and high temperatures where the spectra of SQ1 and SQ2 at $298 \mathrm{~K}$ appear broad and complex, as discussed above, signifying some degree of aggregation is occurring. Conversely, upon heating the samples to $343 \mathrm{~K}$ large changes in the spectra are observed whereby the signals become sharp and well-resolved allowing complete characterization of all ${ }^{1} \mathrm{H}$ signals at this temperature. For example, Figure 2 exemplifies the apparent differences between the ${ }^{1} \mathrm{H}$ NMR spectrum of SQ2 at 298 and $343 \mathrm{~K}$. Interestingly, signals associated with the naphthalimide moiety appear to resolve from two broad signals per proton to become one wellresolved signal for each proton. Moreover, the signals associated with the 3,5-bis(trifluoromethyl)phenyl portion of the molecule appear to undergo significant chemical shift changes, particularly the protons at the 2 and 6 position $\left(\mathrm{H}_{\mathrm{b}}\right)(\Delta \delta=105 \mathrm{~Hz}$. Similarly, the $\mathrm{CH}_{2}$ directly attached to the squaramide moiety also resolves from two signals to one but does not fully resolve to the expected multiplicity and remains broad (Figure S20). Perhaps most striking is the fact that the squaramide $\mathrm{NH}$ signals appear as two distinct signals in the ${ }^{1} \mathrm{H}$ NMR (10.1 and $9.56 \mathrm{ppm}$ ) at $298 \mathrm{~K}$ but are resolved to one broad signal at $9.78 \mathrm{ppm}$ at $343 \mathrm{~K}$. Taken together the evidence from the above study suggests that the entire molecule is taking part in aggregation behavior with the 


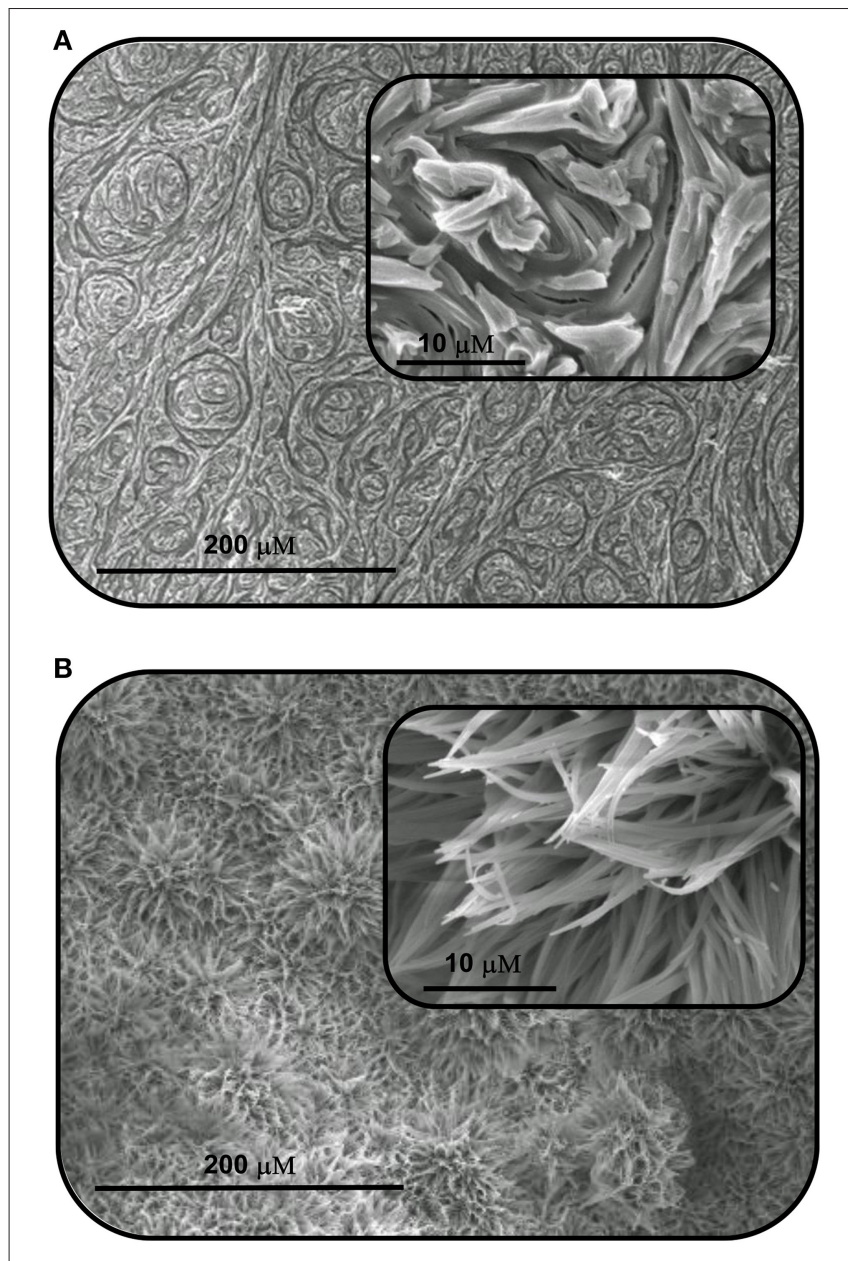

FIGURE 3 | Scanning electron microscopy (SEM) images of the aggregates formed by self-assembly of (A) SQ1 and (B) SQ2 in DMSO.

squaramide, naphthalimide and 3,5-bis(trifluoromethyl)phenyl portions all playing a role. Similar behavior was observed in the cases of both SQ1 and SQ2 (Figure S19).

In order to further probe the aggregation characteristics of both compound, attempts were made to grow crystals from concentrated DMSO solutions. Unfortunately, in our hands the compounds did not crystallize and instead formed what appeared to be amorphous solids. The morphological features of these solids were thus analyzed by scanning electron microscopy (SEM), and as shown in Figure 3, the SEM images exhibit interesting and distinct morphology on the nanoscale. SQ1 appeared as "swirls" that propagate throughout the entire material. Conversely, SQ2 formed showed a sponge like structure that at higher magnification appears to be composed of small nanofilaments. Although firm conclusions cannot be drawn on the exact molecular interactions that give rise to such interesting morphology it is clear that a high degree of aggregation is occurring that appears to be in an ordered fashion to give rise to such patterns.

Both SQ1 and SQ2 were examined using UV/Vis spectroscopy and fluorescence emission spectroscopy. The UV/Vis absorption spectrum of SQ1 in DMSO showed three absorption maxima at 280,340, and $445 \mathrm{~nm}$ with extinction coefficient values of 32,642, 19,559, and $15,439 \mathrm{M}^{-1}$ respectively. Similarly, SQ2 showed an almost identical spectrum to SQ1 with maxima also at 280, 340, and $445 \mathrm{~nm}$ and with extinction coefficients of $34,785,20,405$, and $13,717 \mathrm{M}^{-1}$, respectively. Furthermore, both compounds exhibited fluorescence emission at ca. $525 \mathrm{~nm}$. With the aggregation behavior observed in the previous section, we also undertook a thermal study to investigate if the fluorescence of SQ1 and SQ2 could be modulated by disaggregation. A temperature dependent fluorescence study was thus undertaken in 5\% aq. DMSO. As seen in Figure 4, both SQ1 and SQ2 exhibited a sharp increase in fluorescence $220-300 \%$ as a function of temperature. These results support the ${ }^{1} \mathrm{H}$ NMR results above where we suggest that both SQ1 and SQ2 aggregate in solution but, upon heating, disassemble thus allowing the fluorescence intensity to increase. Interestingly, upon cooling the emission does not decrease to its original value. This may suggest that once disrupted the self-aggregation behavior is not reversible under these conditions (Figure S23). A fluorescence dilution study was also conducted, where it was observed that the fluorescence intensity of both SQ1 and SQ2 at $525 \mathrm{~nm}$ is linear to concentration (from 0.05 to $5 \mu \mathrm{M}$ ) and suggests that aggregation occurs at very low concentrations (Figure S24).

With the observed properties exhibited by SQ1 and SQ2 and the known propensity of squaramides to bind strongly to halides and other anionic species (Prohens et al., 1998, 2001; Piña et al., 2008; Amendola et al., 2010; Busschaert et al., 2012; DelgadoPinar et al., 2012; Jin et al., 2013), we expected that introduction of anionic analytes may also disrupt the self-aggregation of the SQ1 and SQ2. If indeed disruption was to occur, we expected some modulation of their photophysical properties would result and potentially give rise to a new class of anion sensors based on disaggregation.

\section{Anion Induced Disaggregation}

To investigate the ability of anions to disrupt the self-aggregation of SQ1 and SQ2 a series of ${ }^{1} \mathrm{H}$ NMR experiments were carried out. Initial qualitative measurements were undertaken using a screening experiment in which 30 equiv. of several anions $\left(\mathrm{AcO}^{-}, \mathrm{H}_{2} \mathrm{PO}_{4}^{-}, \mathrm{SO}_{4}^{2-}, \mathrm{F}^{-}, \mathrm{Cl}^{-}, \mathrm{Br}^{-}\right.$, and $\mathrm{I}^{-}$as their tetrabutylammonium salts) were added to the receptors in solution $\left(0.5 \% \mathrm{H}_{2} \mathrm{O}\right.$ in DMSO- $\left.\mathrm{d}_{6}\right)$. These preliminary results showed significant changes of the spectra of both SQ1 and SQ2. Dramatic changes were observed in the ${ }^{1} \mathrm{H}$ NMR spectra of both receptors in the presence of $\mathrm{AcO}^{-}, \mathrm{F}^{-}, \mathrm{H}_{2} \mathrm{PO}_{4}^{-}$, and $\mathrm{SO}_{4}^{2-}$ where addition of these anions led to the disappearance of the $\mathrm{NH}$ signal $\left(\mathrm{H}_{\mathrm{a}}\right)$ as shown in Figure 5 for SQ2 and also either broadened $\left(\mathrm{AcO}^{-}\right.$and $\left.\mathrm{F}^{-}\right)$or sharpened $\left(\mathrm{H}_{2} \mathrm{PO}_{4}^{-}\right.$and $\left.\mathrm{SO}_{4}^{2-}\right)$.

Stark color changes of the solutions of SQ1 and SQ2 were observed upon the addition of $\mathrm{F}^{-}$from yellow to red. The disappearance of the $\mathrm{NH}$ signal $\left(\mathrm{H}_{\mathrm{a}}\right)$ and the stark color change suggests that deprotonation of the squaramide/naphthalimide may be responsible. We further confirmed this deprotonation behavior by observation of bifluoride $\left(\mathrm{HF}_{2}^{-}\right)$in the ${ }^{1} \mathrm{H} \mathrm{NMR}$ spectra of SQ1 and SQ2 upon the addition of $\mathrm{F}^{-}$as shown in Figure 5 for receptor SQ1. Moreover, distinct changes were 


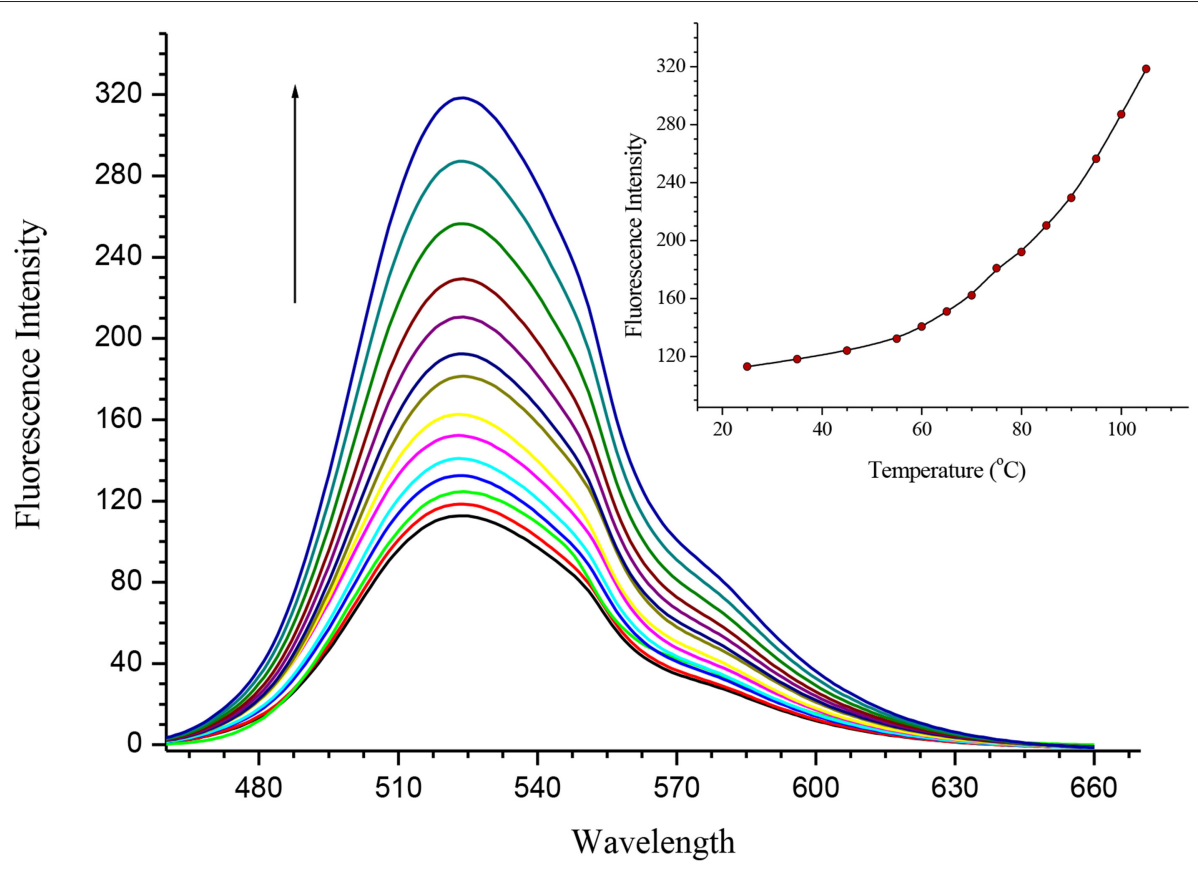

FIGURE 4 | Fluorescence temperature study demonstrating the disaggregation response of $\mathbf{S Q 2}\left(5.0 \times 10^{-6} \mathrm{M}\right)$ in $5 \%$ aq. DMSO from $25^{\circ}$ to $110^{\circ} \mathrm{C}$.

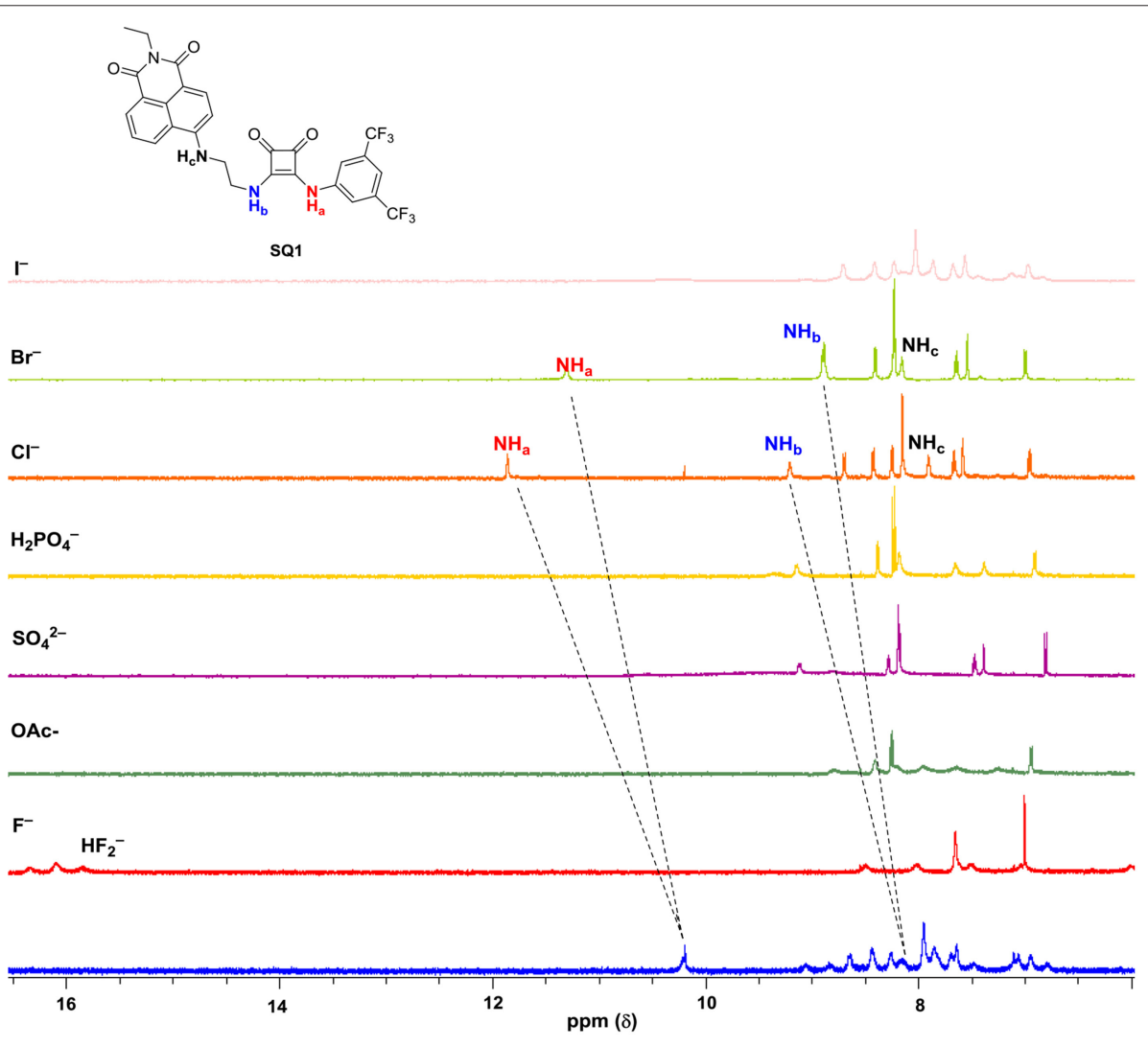

FIGURE $5 \mid{ }^{1} \mathrm{H}$ NMR stackplot of SQ1 with various anions (30 equivalents) in $0.5 \% \mathrm{H}_{2} \mathrm{O}$ in DMSO-d 6 at $298 \mathrm{~K}$. 
observed in the ${ }^{1} \mathrm{H}$ NMR spectra of SQ1 and SQ2 upon the addition of $\mathrm{Cl}^{-}$and $\mathrm{Br}^{-}$. For example, with $\mathbf{S Q 2}$ these halides led to a large downfield shift of the $\mathrm{NH}$ signal $\left(\mathrm{H}_{\mathrm{a}}\right)$ from 10.2 to 12.1 $\mathrm{ppm}$ for $\mathrm{Cl}^{-}$and to $11.1 \mathrm{ppm}$ for $\mathrm{Br}^{-}$coupled with a significantly sharpened signal. Similar behavior was observed for SQ1 (see Figure S25). The large downfield shift of the NH signal suggests a classical $\mathrm{H}$-bonding interaction between $\mathrm{Cl}^{-}$and $\mathrm{Br}^{-}$and the $\mathrm{NH}$ protons of the squaramides. To further investigate the binding interaction of halides with SQ1 and SQ2 more detailed ${ }^{1} \mathrm{H}$ NMR spectroscopic titrations were carried out with halides $\mathrm{F}^{-}, \mathrm{Cl}^{-}, \mathrm{Br}^{-}$, and $\mathrm{I}^{-}$as their tetrabutylammonium salts with the

TABLE 1 | Summary of the halide association constants $\mathrm{K}_{\mathrm{a}}\left(\mathrm{M}^{-1}\right)$ of receptors SQ1 and SQ2 in DMSO- $d_{6}$ at $273 \mathrm{~K}$ according to the ${ }^{1} \mathrm{H}$ NMR titration data.

\begin{tabular}{lcccr}
\hline \multirow{2}{*}{ Receptor } & \multicolumn{4}{c}{$\boldsymbol{K}_{\mathbf{a}}\left(\mathbf{M}^{-\mathbf{1}}\right) \mathbf{( \%}$ Error) } \\
\cline { 2 - 5 } & $\mathbf{F}^{-}$ & $\mathbf{C l}^{-}$ & $\mathbf{B r}^{-}$ & $\mathbf{I}^{-}$ \\
\hline SQ1 & $-^{\mathrm{a}}$ & $489(6 \%)$ & $165(10 \%)$ & $-^{\mathrm{b}}$ \\
SQ2 & $-^{\mathrm{a}}$ & $221(9 \%)$ & $99(9 \%)$ & $-^{\mathrm{b}}$
\end{tabular}

${ }^{a}$ Addition of $F^{-}$resulted in deprotonation and prevented an association constant from being determined.

${ }^{b}$ Spectral changes were too minor to provide an accurate association constant. A series of equilibria may occur in solution under the reported conditions (e.g., aggregate disruption, anion binding to the monomer; anion binding to the aggregate etc.) thus these data, that have been fitted to a 1:1 binding model, are included to give a comparison of analogous squaramide anion receptors previously reported Busschaert et al., 2012; Bao et al., 2018. resulting data fit to a 1:1 binding model using the open access BindFit software program (Thordarson, 2011; Lowe et al., 2012; Brynn Hibbert and Thordarson, 2016) to provide the apparent stability constants $\left(\mathrm{K}_{\mathrm{a}}\right)$, which are summarized in Table 1 .

As an example, Figure 6 shows the changes observed in the ${ }^{1} \mathrm{H}$ NMR spectrum of SQ1 upon the addition of $\mathrm{Cl}^{-}$(20 equiv.). A gradual downfield shift of the $\mathrm{NH}$ signal $\left(\mathrm{H}_{\mathrm{a}}\right)$ from 10.2 to $11.8 \mathrm{ppm}$ in the ${ }^{1} \mathrm{H}$ NMR spectrum was observed upon the increasing concentration of $\mathrm{Cl}^{-}$. These changes together with increased spectral resolution observed over the entire spectrum upon the addition of $\mathrm{Cl}^{-}$, clearly support a classical $\mathrm{H}$-bonding interaction between $\mathrm{Cl}$ and the $\mathrm{NH}$ protons $\left(\mathrm{H}_{\mathrm{a}}\right)$ of the receptors.

Overall, both SQ1 and SQ2 were found to bind to $\mathrm{Cl}^{-}$and $\mathrm{Br}^{-}$ with moderate affinities with SQ1 showing a slightly increased affinity for both anions compared to SQ2 where the position of the squaramide at the "tail" of the naphthalimide seems to be optimal for both anions. Similarly, both receptors exhibited a preference for $\mathrm{Cl}^{-}$over $\mathrm{Br}^{-}$while $\mathrm{I}^{-}$showed an almost complete lack of binding in both cases. Conversely, as previously discussed $\mathrm{F}^{-}$resulted in receptor deprotonation thus the data could not be fit to a suitable ${ }^{1} \mathrm{H}$ NMR binding model. Analysis of the ${ }^{1} \mathrm{H}$ NMR spectra of the complexes also provided further evidence for the disaggregation of SQ1 and SQ2 in the presence of $\mathrm{Cl}^{-}$ and $\mathrm{Br}^{-}$where the bound receptors gave rise to a well-resolved spectrum with sharp signals that could be clearly attributed to the proposed target structures. In addition, the signal for the $\mathrm{CH}_{2}$ protons directly attached to the squaramide moiety in both

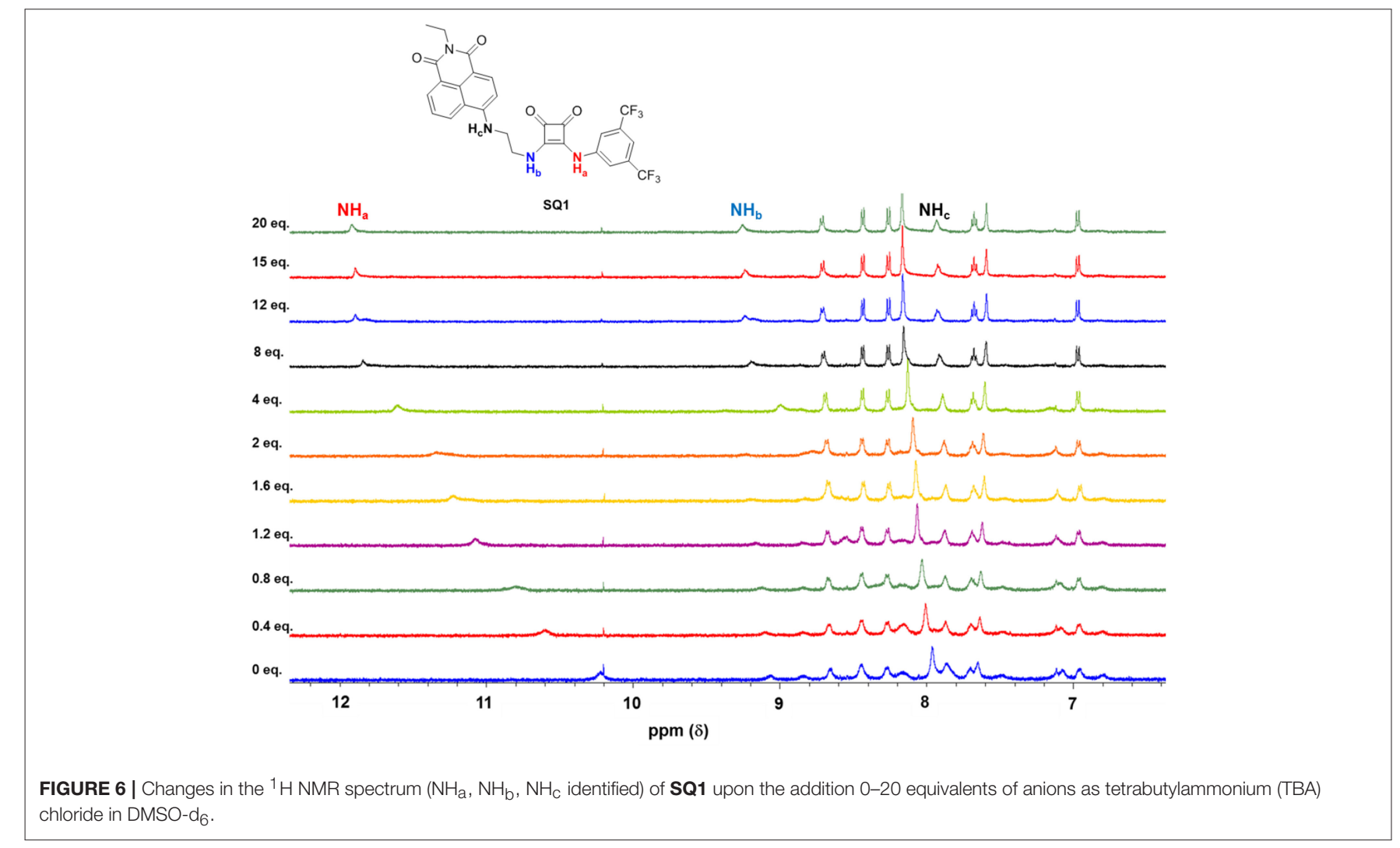


cases resolved from two broad signals to one single signal with significantly improved resolution (Figures S20, S21).

While conducting the ${ }^{1} \mathrm{H}$ NMR experiments we also noticed samples containing $\mathrm{Cl}^{-}$and $\mathrm{Br}^{-}$exhibited significantly more intense fluorescence than the parent receptors in solution when irradiated with UV light. This chance observation led us to investigate the fluorescence behavior of SQ1 and SQ2 upon titration with the halides in more detail.

Having observed such stark changes in the ${ }^{1} \mathrm{H}$ NMR titrations of SQ1 and SQ2 in the presence of halides we next wished to investigate their excited state properties in the presence of $\mathrm{F}^{-}, \mathrm{Cl}^{-}, \mathrm{Br}^{-}$, and $\mathrm{I}^{-}$. Titrations were performed in $5 \%$ aq. DMSO with addition of aliquots of the anions as their tetrabutylammonium salts. Both receptors exhibited emission with maxima at ca. $525 \mathrm{~nm}$ in solution. As shown in Figure 7 additions of the halides resulted in varying effects. In the presence of $\mathrm{I}^{-}$minor changes were observed where a small increase in emission intensity (20-25\%) was observed up to a concentration of $20 \mathrm{mM}$. Addition of $\mathrm{F}^{-}$on the other hand, was found to result in a large decrease in emission intensity (80-85\%) culminating in the both SQ1 and SQ2 largely appearing as non-fluorescent. We ascribe this behavior to the deprotonation observed in the NMR titrations and similar behavior was also observed in the presence of basic non-halide anions such as $\mathrm{AcO}^{-}, \mathrm{H}_{2} \mathrm{PO}_{4}^{-}, \mathrm{SO}_{4}^{2-}$. Most strikingly, however, was the observation of large fluorescence increases in the presence of both $\mathrm{Cl}^{-}$and $\mathrm{Br}^{-}$where the addition of $\mathrm{Cl}^{-}$resulted in a 98 and $170 \%$ enhancement of emission from SQ1 and SQ2, respectively, while, unexpectedly, $\mathrm{Br}^{-}$resulted in a 500 and $600 \%$ enhancement of emission from SQ1 and SQ2, respectively. From the previous temperature dependent fluorescence study, we suggest that the emission enhancement is as a result of the disaggregation of SQ1 and SQ2 in solution where aggregation induced self-quenching is disrupted allowing the release of monomers in solution and thus a recovery in fluorescence. Moreover, these responses were also clearly visible to the naked eye under UV illumination (Figure 7B). In order to investigate the effect of water on the fluorescence response, qualitative titrations were also performed in non-aqueous DMSO and in $20 \%$ aq. DMSO. We observed that the selective response to $\mathrm{Br}^{-}$in pure DMSO was similar to that seen in $5 \%$ aq DMSO while in $20 \%$ aq. DMSO the response was considerably less defined. These results suggest that water concentration has a significant effect on the aggregation behavior of both SQ1 and SQ2 and thus their ability to act as halide sensors in fully aqueous environments (Figures S27, 28).

Nevertheless, in order to investigate the sensing responses of SQ1 and SQ2 in more detail, fluorescence titrations were performed with 0.0-100.0 equivalent increments of halides in $5 \%$ aq. DMSO. As seen in the qualitative experiments the fluorescence intensity of both receptors is quenched by $80-85 \%$ upon addition of $\mathrm{F}^{-}$while minor fluorescence enhancements are observed for $\mathrm{I}^{-}$. However, a larger degree of enhancement (98-170\%) is observed upon addition of $\mathrm{Cl}^{-}$ and, most interestingly, we observed a 500-600\% increase in fluorescence intensity centered at $525 \mathrm{~nm}$ upon addition of $\mathrm{Br}^{-}$(Figure 8).

These results demonstrate that both SQ1 and SQ2 show a selective fluorescence response toward $\mathrm{Br}^{-}$when compared against other halides. This result is particularly unexpected given the NMR studies above where the binding of SQ1 and SQ2 to $\mathrm{Cl}^{-}$appears to be considerably stronger when measured by ${ }^{1} \mathrm{H}$ NMR titration. Moreover, the desired "OFF-ON" fluorescence response paves the way for SQ1 and SQ2 to be used as selective bromide sensors with potential industrial/medical application. Limit of detection (LOD) values were estimated using a standard deviation method $(\mathrm{LOD})=(3 \mathrm{~S} / \mathrm{m}$, in which $\mathrm{S}$ is the standard deviation of blank measurements, $n$ $=11$, and $\mathrm{m}$ is the slope of the linear equation) (Kumar et al., 2016), where SQ1 and SQ2 were found to exhibit LOD values in the $\mu \mathrm{M}$ range; values that are adequate to measure trace levels of halide contamination. A summary of the fluorescence quenching/enhancement characteristics and LOD values for SQ1 and SQ2 in the presence of the halides are listed in Table 2.

\section{Evaluation of SQ1 and SQ2 in a Human Cell Line}

With the observed spectroscopic responses and the potential application of SQ1 and SQ2 as bromide sensors we also

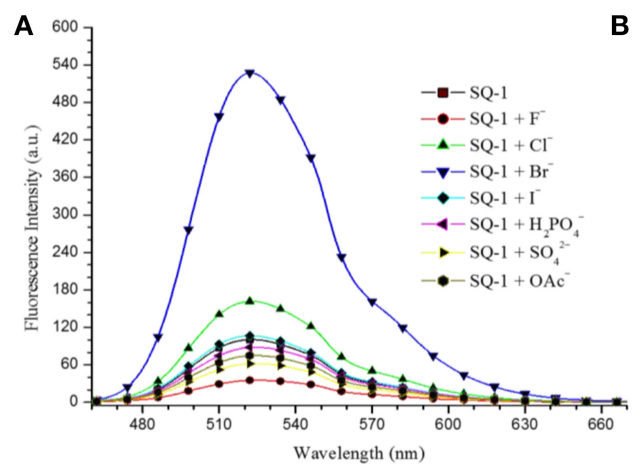

B

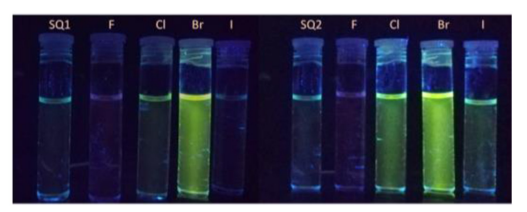

FIGURE 7 | (A) Fluorescence response of SQ1 (5 $\mu$ M) in 5\% aq. DMSO toward different TBA anions (20 mM). ( $\lambda$ ex. $435 \mathrm{~nm})$. (B) Fluorescence response of SQ1 and SQ2 toward various halides in 5\% aq DMSO after UV illumination as seen by the naked eye. 
wished to evaluate their biocompatibility in a human cell line. Gale and co-workers have recently reported analogous naphthalimide-squaramide conjugates for use as anion receptors and transmembrane anion transporters where they found that the most active anion transporter [which also contained a 3,5-bis(trifluoromethyl)phenyl squaramide moiety] was readily internalized in human lung carcinoma A549 cells and exhibited no toxicity up to a concentration of $100 \mu \mathrm{M}$ as determined using a CCK-8 assay (Bao et al., 2018). Thus we set out to conduct an initial evaluation of SQ1 and SQ2 uptake and behavior in cells. Firstly, the ability of SQ1 and SQ2 to be internalized into cells was assessed using confocal microscopy in HeLa cells, a widely-used cervical carcinoma cell line. HeLa cells $\left(0.5 \times 10^{5}\right)$ were incubated with either SQ1 or SQ2 (either 20,5 , or $1 \mu \mathrm{M}$ ) at $37^{\circ} \mathrm{C}$ for $1 \mathrm{~h}$ before the cells were fixed, and mounted for microscopy. Figure 9 shows examples of cells incubated with SQ1 and SQ2 at $5 \mu \mathrm{M}$, demonstrating successful uptake, as all cells in the sample emitted strong green fluorescence. SQ1 and SQ2 appear to localize in the cytoplasm as co-localization studies with the nucleic acid stain DAPI (blue) suggest that neither SQ1 nor SQ2 enter the nucleus. Uptake of both compounds was also investigated in a more quantitative manner using flow cytometry where, again, both SQ1 and SQ2 were rapidly taken up by HeLa cells. Resulting histogram plots show an increase in mean fluorescence intensity in a concentration-dependent manner and a clear shift for the entire cell population, demonstrating that all cells successfully internalized the compounds (Figure 9).

Cellular viability in the presence of SQ1 and SQ2 was measured using an MTT assay where the results showed that the $\%$ viability of $\mathrm{HeLa}$ cells decreased in a dosedependent manner in the presence of SQ1 and SQ2, with SQ2 showing higher levels of cytotoxicity compared to SQ1. SQ1 appeared to be largely non-toxic up to $1 \mu \mathrm{M}$ while SQ2 at $1 \mu \mathrm{M}$ showed \% cell viability at $28 \%( \pm 20 \%)$ (see Figure S42). Gale and co-workers reported no toxicity up to a concentration of $100 \mu \mathrm{M}$ for their 1,8-naphthalimidesquaramide conjugates, while SQ1, which is structurally very similar to the compounds reported by Gale, was shown to be considerably more cytotoxic under these conditions (Bao et al., 2018). Finally, we wished to determine whether the $\mathrm{Br}^{-}$sensing abilities of these compounds could be measured in cellulo. As mentioned above O'Shea (Wu et al., 2018) and others (Zhai et al., 2014) have already exploited a disaggregation approach to sensing in a biological environment, thus we sought to investigate if SQ1 and SQ2 could measure bromide contamination in cells. Indeed, as shown in Figure 10, flow cytometry analysis was able to show a further increase in fluorescence intensity for cells incubated with SQ1 or SQ2 in the presence of sodium bromide $(50 \mathrm{mM})$ compared to those incubated with the squaramide receptors in the absence of sodium bromide.

\section{CONCLUSIONS}

The field of molecular recognition continues to grow with ever more elegant receptors being reported that are capable of selective recognition for various anions using a diverse set of

TABLE 2 | Summary of the fluorescence quenching/enhancement characteristics and the Limit of Detection (LOD) values obtained for SQ1 and SQ2 in the presence of halides.

\begin{tabular}{|c|c|c|c|}
\hline Probe & Anions & $\begin{array}{l}\text { Fluorescence } \\
\text { response }\end{array}$ & $\begin{array}{c}\text { Detection } \\
\text { limit (LOD = } \\
\text { 3r/slope) }\end{array}$ \\
\hline \multirow[t]{4}{*}{ SQ1 } & $\mathrm{F}^{-}$ & 80\% Quenching & $6.25 \times 10^{-6} \mathrm{M}$ \\
\hline & $\mathrm{Cl}^{-}$ & 98\% Enhancement & $9.65 \times 10^{-5} \mathrm{M}$ \\
\hline & $\mathrm{Br}^{-}$ & $500 \%$ Enhancement & $1.33 \times 10^{-5} \mathrm{M}$ \\
\hline & $1^{-}$ & $20 \%$ enhancement & $8.03 \times 10^{-4} \mathrm{M}$ \\
\hline \multirow[t]{4}{*}{ SQ2 } & $\mathrm{F}^{-}$ & 85\% Quenching & $5.58 \times 10^{-6} \mathrm{M}$ \\
\hline & $\mathrm{Cl}^{-}$ & 170\% Enhancement & $7.86 \times 10^{-5} \mathrm{M}$ \\
\hline & $\mathrm{Br}^{-}$ & 600\% Enhancement & $1.92 \times 10^{-5} \mathrm{M}$ \\
\hline & $1^{-}$ & 25\% enhancement & $5.51 \times 10^{-4} \mathrm{M}$ \\
\hline
\end{tabular}

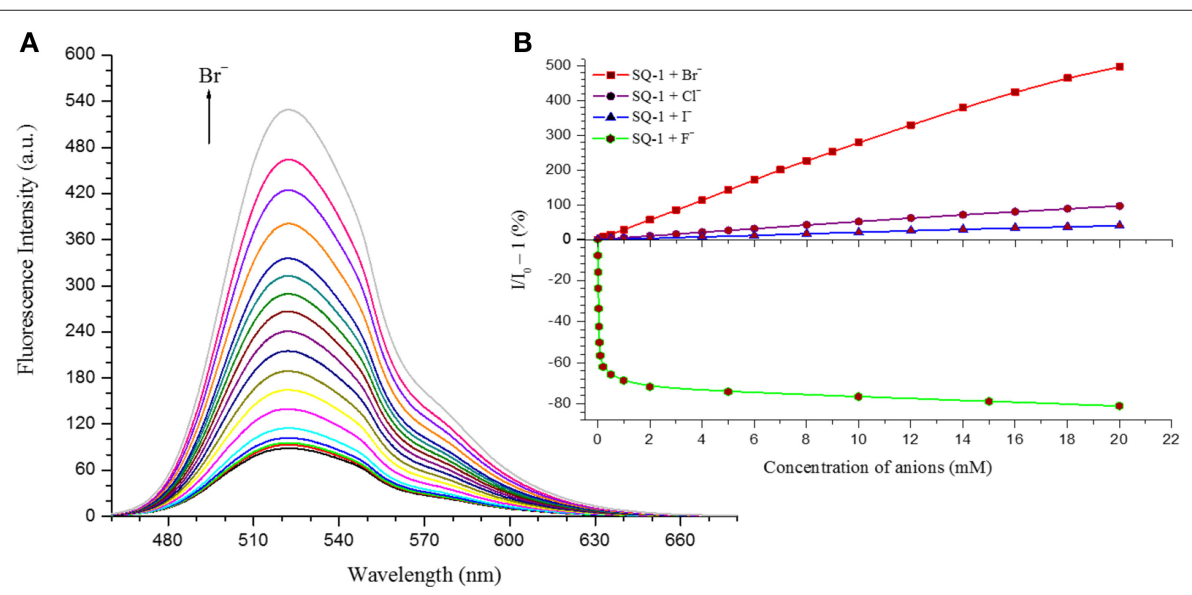

FIGURE 8 | (A) Changes in the fluorescence response of SQ1 in the presence of $\mathrm{Br}^{-}$in $5 \%$ aq. DMSO (B) Relative fluorescence enhancement and quenching response of SQ1 with different halides in 5\% aq. DMSO. 

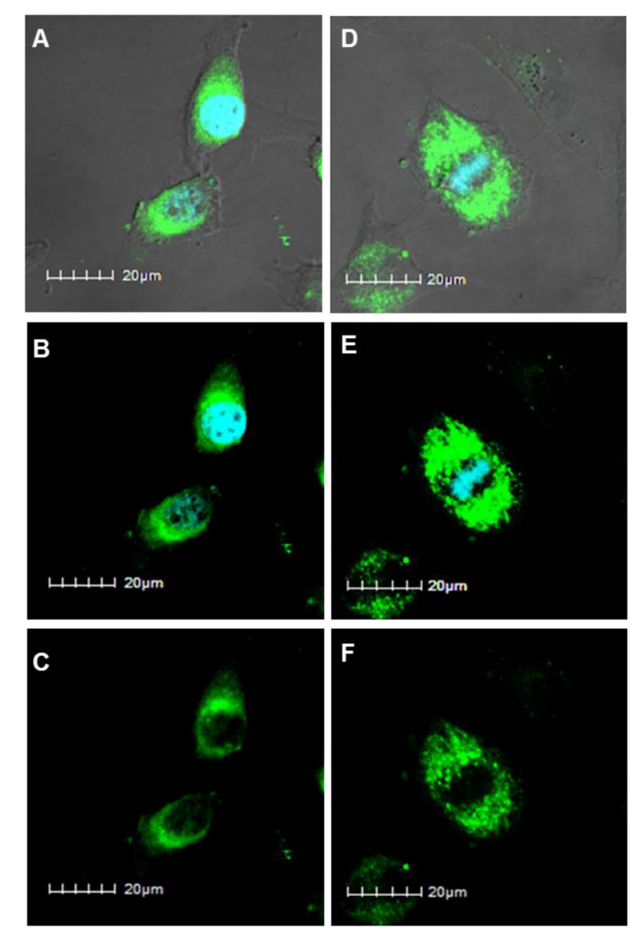

G 2.00

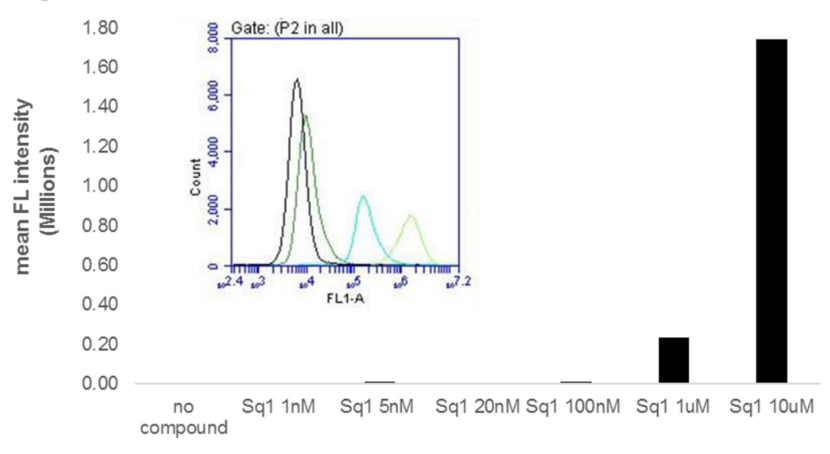

H $\quad 0.90$

0.80

0.70

竞 0.60

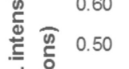

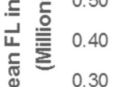

$\begin{array}{ll}\stackrel{\Phi}{E} & 0.30 \\ & 0.20\end{array}$

0.20

0.00

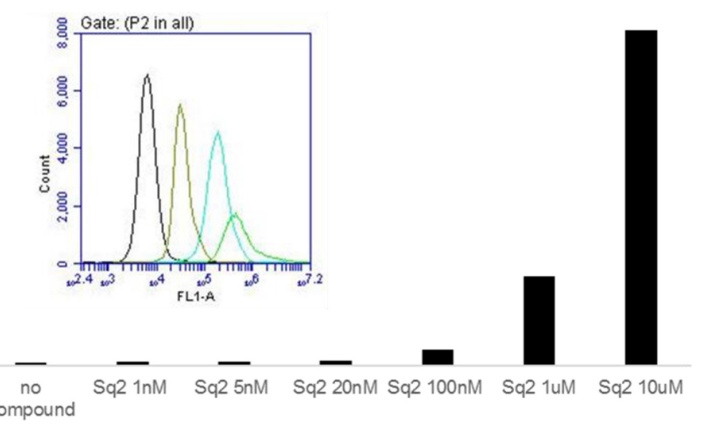

FIGURE 9 | Uptake of SQ1 and SQ2 $(5 \mu \mathrm{M})$ by HeLa cells. (A-F) shows images obtained by confocal microscopy. (A) shows an overlay of the bright field image of treated cells with the DAPI (4',6-diamidino-2-phenylindole) signal (blue) and SQ1 (green), (B) shows overlay of SQ1 (green) and nuclear co-stain DAPI (blue), (C) shows SQ1 fluorescence alone (green), (D) shows an overlay of the bright field image of treated cells with the DAPI signal (blue) and SQ2 (green), (B) shows overlay of SQ2 (green) and nuclear co-stain DAPI (blue), (C) shows SQ2 fluorescence alone (green). Scale bars: $20 \mu \mathrm{m}$. Additional images displayed in the Supporting Information. (G,H) shows flow cytometry data for SQ1 and SQ2, respectively. Bar charts show the mean fluorescence intensity (FL-1) obtained in a representative experiment (out of two) with cells treated with SQ1 or SQ2 over a wide range of concentrations (1 nm-10 $\mu \mathrm{M}$ ). In addition, histogram plots for FL-1 are also shown to illustrate the clear shift in FL-1 for the entire cell population (untreated cells (black), $100 \mathrm{nM}, 1,10 \mathrm{uM}$ ).

approaches. Indeed, with our experience of studying squaramide based probes we have attempted to uncover an alternative approach for selective detection of a somewhat neglected halide; $\mathrm{Br}^{-}$. In this study we have reported the synthesis of two new squaramide-naphthalimide conjugates based on a "head to head" or "head to tail" design. We initially discovered that both probes SQ1 and SQ2 displayed a large degree of selfaggregation in aqueous DMSO solution that could be disrupted at increased temperature as studied by ${ }^{1} \mathrm{H}$ NMR and SEM. Moreover, we also discovered that the fluorescence behavior of both receptors was highly dependent upon the aggregation state and disruption of aggregation by increasing temperature gave rise to a significant increase in fluorescence intensity. We therefore exploited this disaggregation induced emission response for the recognition of halides, where we discovered that the receptors gave rise to distinct responses related to the interaction of the various halide anions with the receptors. Addition of $\mathrm{F}^{-}$ rendered both compounds non-emissive; thought to be due to a deprotonation event while, surprisingly, $\mathrm{Br}^{-}$resulted in a dramatic 500-600\% fluorescence enhancement thought to be due to a disruption of compound aggregation and allowing the monomeric receptors to dominate in solution. Furthermore, optical sensing parameters such as limits of detection and binding constant of probes were also measured toward the various halides $\left(\mathrm{F}^{-}, \mathrm{Cl}^{-}, \mathrm{Br}^{-}\right.$, and $\left.\mathrm{I}^{-}\right)$where both SQ1 and SQ2 were found to sense halides with adequate sensitivity to measure $\mu \mathrm{M}$ levels of halide contamination. Finally, initial studies in a human cell line were also conducted where it was observed that both compounds are easily taken up by HeLa cells, exhibiting strong intracellular fluorescence as measured by both confocal microscopy and flow cytometry. We were also able to demonstrate that SQ1or SQ2- containing Hela cells treated with $\mathrm{NaBr}$ exhibited increased fluorescence intensity. While the observed increases in fluorescence intensity were modest in relation to those observed in the spectroscopic titrations described above, cell cytometry analysis allowed some distinction to be made. Given the complex environment of the cellular cytoplasm, the fully aqueous environment and the presence of intracellular $\mathrm{Cl}^{-}$at high concentrations (ranging from 5 to $80 \mathrm{mM}$ in mammalian cells) (Andersen, 2013) it is not surprising that the response is considerably less pronounced. Solvent effects are also likely to play a major role in the anion response. To the best of our knowledge, SQ1 and SQ2 are the first such fluorescent sensors capable of sensing $\mathrm{Br}^{-}$in cellulo and we are currently working toward sensors with an improved bromide sensitivity and cellular cytotoxicity profile. 

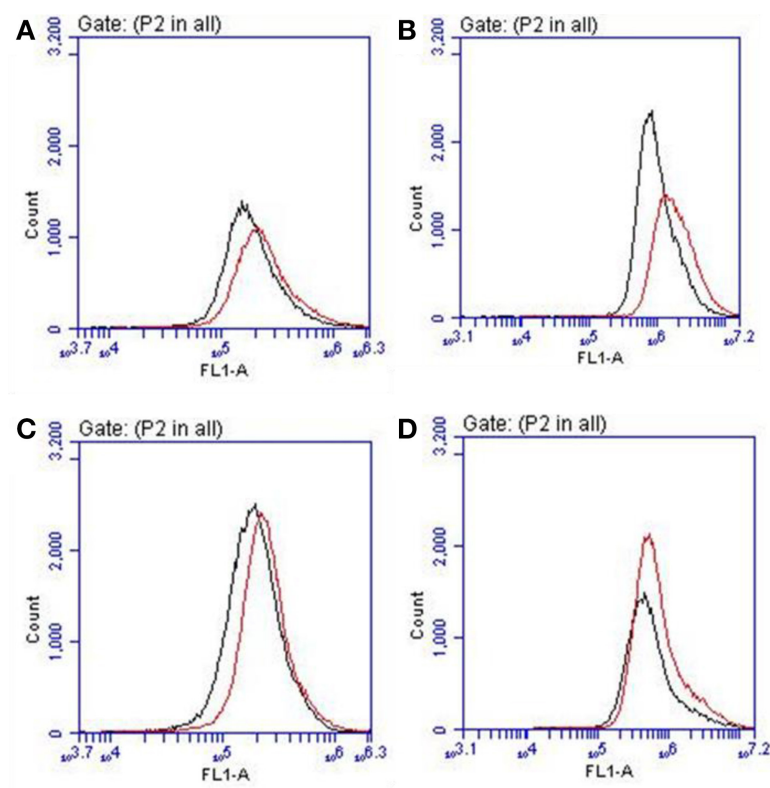

FIGURE 10 | Flow cytometry histogram plots for HeLa cells incubated with (A) SQ1 $(1 \mu \mathrm{M}),(\mathbf{B}) \mathbf{S Q 1}(10 \mu \mathrm{M}), \mathbf{C}) \mathbf{S Q 2}(1 \mu \mathrm{M})$, and (D) SQ2 $(10 \mu \mathrm{M})$ in the absence (black) or presence of $\mathrm{NaBr}$ (red).

\section{EXPERIMENTAL SECTION}

\section{3-((3,5-bis(trifluoromethyl)phenyl)amino)-4- ethoxycyclobut-3-ene-1,2-dione (1)}

A solution of 3,5 -bis(trifluoromethyl)aniline $(1.835 \mathrm{~mL}, 11.75$ $\mathrm{mMol}, 1 \mathrm{eq})$ in EtOH $(5 \mathrm{~mL})$ was slowly added to a mixture of diethyl squarate $(1.74 \mathrm{~mL}, 11.75 \mathrm{mMol}, 1 \mathrm{eq})$ and zinc triflate $(0.85 \mathrm{~g}, 2.35 \mathrm{mMol}, 0.2 \mathrm{eq})$ in $5 \mathrm{~mL} \mathrm{EtOH}$. The reaction was stirred at room temperature overnight. The precipitate was collected by suction filtration and washed with $\mathrm{EtOH}$ and $\mathrm{Et}_{2} \mathrm{O}$ to yield the product as an off-white amorphous solid ( $3.28 \mathrm{~g}$, 79\%). ${ }^{1}$ H NMR, (DMSO- $\left.d_{6}, 500.13 \mathrm{MHz}\right) \delta(\mathrm{ppm}), \mathrm{J}(\mathrm{Hz}): 1.41$ $\left(\mathrm{t}, J=7.1,3 \mathrm{H}, \mathrm{CH}_{3}\right), 4.79\left(\mathrm{q}, J=7.1,2 \mathrm{H}, \mathrm{CH}_{2}\right), 7.78(\mathrm{~s}, 1 \mathrm{H}$, phenylene $\mathrm{H}), 8.03$ (s, $2 \mathrm{H}$, phenylene $\mathrm{H}), 11.19$ (br, $1 \mathrm{H}, \mathrm{NH}$ ); ${ }^{13}$ C NMR (DMSO- $\left.d_{6}, 125.76 \mathrm{MHz}\right): \delta(\mathrm{ppm}): 184.9,179.7,140.6$, $131.7,131.4,131.2,126.8,124.6,122.4,119.9,116.8,70.5,15.8$; HRMS (ESI) calcd. for $\mathrm{C}_{14} \mathrm{H}_{10} \mathrm{~F}_{6} \mathrm{NO}_{3}[\mathrm{M}+\mathrm{H}]^{+} 354.056$, found 354.0554; $v_{\max }(\mathrm{KBr}) / \mathrm{cm}^{-1}: 3,254,3,185,3,100,3,062,3,004$, $1,816,1,717,1,603,1,476,1,453,1,278,1,233,1,170,1,101,1,042$, 997, and 936 .

\section{6-bromo-2-ethyl-1H- benzo[de]isoquinoline-1,3(2H)-dione (2a)}

4-Bromo-1,8-naphthalic anhydride $(2.0 \mathrm{~g}, 7.33 \mathrm{mMol}, 1 \mathrm{eq})$ was mixed with ethylamine $(0.57 \mathrm{~mL}, 8.66 \mathrm{mMol}, 1.2 \mathrm{eq})$ in $\mathrm{EtOH}$ $(10 \mathrm{~mL})$. The reaction mixture was refluxed at $80^{\circ} \mathrm{C}$ for $24 \mathrm{~h}$. The precipitate was collected by suction filtration and washed with $\mathrm{EtOH}$ and $\mathrm{Et}_{2} \mathrm{O}$ to yield the product as a light tan amorphous solid (1.74 g, 79\%). ${ }^{1} \mathbf{H}$ NMR, (DMSO- $\left.d_{6}, 500.13 \mathrm{MHz}\right) \delta(\mathrm{ppm}), J$ $(\mathrm{Hz}): 1.21\left(\mathrm{t}, J=7.0,3 \mathrm{H}, \mathrm{CH}_{3}\right), 4.06\left(\mathrm{q}, J=7.0,2 \mathrm{H}, \mathrm{CH}_{2}\right), 7.99(\mathrm{t}$, $J=8.0,1 \mathrm{H}$, phenylene $\mathrm{H}), 8.21(\mathrm{~d}, J=7.8,1 \mathrm{H}$, phenylene $\mathrm{H}), 8.32$ $(\mathrm{d}, J=7.8,1 \mathrm{H}$, phenylene $\mathrm{H}), 8.55(\mathrm{q}, J=7.8,2 \mathrm{H}$, phenylene $\mathrm{H})$;
${ }^{13}$ C NMR (DMSO- $d_{6}, 125.76 \mathrm{MHz}$ ): $\delta$ (ppm): 163.1, 163.1, 133.0, $132.0,131.8,131.4,130.3,129.5,129.3,128.8,123.3,122.5,35.4$, 13.5; HRMS (ESI) calcd. for $\mathrm{C}_{28} \mathrm{H}_{20} \mathrm{Br}_{2} \mathrm{~N}_{2} \mathrm{NaO}_{4}[2 \mathrm{M}+\mathrm{Na}]^{+}$ 628.968, found 628.9599; $v_{\max }(\mathrm{KBr}) / \mathrm{cm}^{-1}: 3,086,2,979,2,939$, $1,921,1,779,1,740,1,693,1,612,1,587,1,568,1,505,1,456,14,35$, $1,401,1,371,1,354,1,339,1,325,1,244,1,227,1,201,1,170,1,150$, $1,095,1,061,1,044,1,021$, and 961 .

\section{6-((2-aminoethyl)amino)-2-ethyl-1H- benzo[de]isoquinoline-1,3(2H)-dione (2b)}

6-bromo-2-ethyl-1H-benzo[de]isoquinoline-1,3(2H)-dione (1 g, $3.288 \mathrm{mMol}, 1 \mathrm{eq})$ was stirred at room temperature overnight in neat ethylenediamine $(10 \mathrm{~mL}$, excess) to yield a dark orange liquid. The crude product was slowly added to deionized water $(50 \mathrm{~mL})$ and left to stir at room temperature for $2 \mathrm{~h}$. The precipitate was collected by suction filtration and washed with $\mathrm{H}_{2} \mathrm{O}$ to yield the product as a yellow amorphous solid $(0.748 \mathrm{~g}$, 80\%), ${ }^{1}$ H NMR, (DMSO- $\left.d_{6}, 500.13 \mathrm{MHz}\right) \delta(\mathrm{ppm}), J(\mathrm{~Hz}): 1.11$ $\left(\mathrm{t}, J=7.0,3 \mathrm{H}, \mathrm{CH}_{3}\right), 2.82\left(\mathrm{t}, J=6.4,2 \mathrm{H}, \mathrm{CH}_{2}\right), 3.32(\mathrm{t}, J=$ 6.4, $\left.2 \mathrm{H}, \mathrm{CH}_{2}\right), 3.97\left(\mathrm{q}, J=7.1,2 \mathrm{H}, \mathrm{CH}_{2}\right), 6.73(\mathrm{~d}, J=8.5$, $1 \mathrm{H}$, phenylene $\mathrm{H}), 7.60(\mathrm{~m}, 1 \mathrm{H}$, phenylene $\mathrm{H}), 8.18(\mathrm{~d}, \mathrm{~J}=8.5$, $1 \mathrm{H}$, phenylene $\mathrm{H}), 8.36(\mathrm{dd}, 1 \mathrm{H}$, phenylene $\mathrm{H}), 8.63(\mathrm{dd}, 1 \mathrm{H}$, phenylene $\mathrm{H}$ ); ${ }^{13} \mathrm{C}$ NMR, (DMSO- $\left.d_{6}, 125.76 \mathrm{MHz}\right) \delta(\mathrm{ppm}): 13.7$, 34.7, 46.7, 104.3, 108.1, 120.6, 122.3, 124.6, 129.0, 129.8, 131.0, 134.6, 151.3, 163.1, 164.0; HRMS (ESI) calcd. for $\mathrm{C}_{16} \mathrm{H}_{18} \mathrm{~N}_{3} \mathrm{O}_{2}$ $[\mathrm{M}+\mathrm{H}]^{+}$284.139, found 284.1389; $\boldsymbol{v}_{\max }(\mathrm{KBr}) / \mathrm{cm}^{-1}: 3,358$, $2,979,1,676,1,612,1,586,1,550,1,461,1,430,1,396,1,370,1,349$, $1,249,1,188,1,152,1,121,1,104,1,066,965$, and 918 .

\section{Tert-butyl(2-aminoethyl)carbamate (3a)}

To a $500 \mathrm{~mL}$ round bottom flask was added ethylenediamine $(13.4 \mathrm{~mL}, 161.86 \mathrm{mMol}, 10 \mathrm{eq})$ in $\mathrm{CHCl}_{3}(100 \mathrm{~mL})$. A solution of di-tert-butyl dicarbonate $(4.4 \mathrm{~g}, 37.56 \mathrm{mMol}, 1 \mathrm{eq})$ in $\mathrm{CHCl}_{3}$ $(50 \mathrm{~mL})$ was added dropwise over $2 \mathrm{~h}$ at $0^{\circ} \mathrm{C}$ and stirred at room for $24 \mathrm{~h}$. The reaction mixture was washed with brine, the organic layer was washed with de-ionized $\mathrm{H}_{2} \mathrm{O}$ and dried over $\mathrm{MgSO}_{4}$. The filtrate was concentrated in vacuo to yield an off-white liquid. (2.012 g, 34\%). ${ }^{1} \mathrm{H}$ NMR, (DMSO- $\left.d_{6}, 500 \mathrm{MHz}\right) \delta$ (ppm), $J(\mathrm{~Hz})$ : $1.36\left(\mathrm{~s}, 9 \mathrm{H}, \mathrm{CH}_{3}\right), 2.51\left(\mathrm{~d}, J=6.5,2 \mathrm{H}, \mathrm{CH}_{2}\right), 2.90(\mathrm{~d}, J=5.8,2 \mathrm{H}$, $\mathrm{CH}_{2}$ ), $6.71(\mathrm{~s}, 1 \mathrm{H}, \mathrm{NH}) ;{ }^{13} \mathrm{C}$ NMR (DMSO- $d_{6}, 125.76 \mathrm{MHz}$ ): $\delta$ (ppm): 28.7, 31.7, 42.0, 44.1, 77.8, 79.6, 156.1 .

\section{Tert-butyl(2-(6-nitro-1,3-dioxo-1H- benzo[de]isoquinolin-2(3H)- yl)ethyl)carbamate (3b)}

Tert-butyl (2-aminoethyl) carbamate $(0.565 \mathrm{~mL}, 3.54 \mathrm{mMol}, 1$ eq) was slowly added dropwise to a solution of 4-Nitro-1,8naphthalic anhydride $(0.86 \mathrm{~g}, 3.54 \mathrm{mMol}, 1 \mathrm{eq})$ in EtOH $(20 \mathrm{~mL})$. The reaction mixture was left to react in a $35 \mathrm{~mL}$ microwave tube for $1 \mathrm{~h}$ at $110^{\circ} \mathrm{C}, 1 \mathrm{mbar}$ and 300 watts. The precipitate was collected by suction filtration and washed with $\mathrm{EtOH}$ and $\mathrm{Et}_{2} \mathrm{O}$ to yield the product as a peach amorphous solid $(1.047 \mathrm{~g}, 76 \%)$. ${ }^{1} \mathrm{H}$ NMR, (DMSO- $\left.d_{6}, 500.13 \mathrm{MHz}\right) \delta(\mathrm{ppm}), J(\mathrm{~Hz}): 1.22(\mathrm{~s}, 9 \mathrm{H}$, $\left.\mathrm{CH}_{3}\right), 3.27\left(\mathrm{t}, J=6.0,2 \mathrm{H}, \mathrm{CH}_{2}\right), 4.14\left(\mathrm{t}, \mathrm{J}=6.0,2 \mathrm{H}, \mathrm{CH}_{2}\right), 6.88$ $(\mathrm{t}, J=6.3,1 \mathrm{H}, \mathrm{NH}), 8.09(\mathrm{t}, J=8.1,1 \mathrm{H}$, phenylene $\mathrm{H}), 8.55(\mathrm{~d}$, $J=8.0,1 \mathrm{H}$, phenylene $\mathrm{H}), 8.62(\mathrm{~m}, 2 \mathrm{H}$, phenylene $\mathrm{H}), 8.71(\mathrm{~d}$, $J=8.4,1 \mathrm{H}$, phenylene $\mathrm{H}) ;{ }^{13} \mathrm{C}$ NMR (DMSO- $d_{6}, 125.76 \mathrm{MHz}$ ): $\delta$ (ppm): 28.5, 38.0, 77.9, 123.1, 123.5, 124.6, 127.3, 128.9, 129.0, 
129.9, 130.5, 132.0, 149.5, 156.2, 162.8, 163.6; HRMS (ESI) calcd. for $\mathrm{C}_{19} \mathrm{H}_{19} \mathrm{~N}_{3} \mathrm{NaO}_{6}[\mathrm{M}+\mathrm{Na}]^{+} 408.117$, found 408.1144; $\boldsymbol{v}_{\max }$ (KBr)/cm ${ }^{-1}$ : 3,401, 3,070, 2,977, 2,935, 1,714, 1,702, 1,623, 1,593, 1,584, 1,523, 1,447, 1,410, 1,365, 1,341, 1,272, 1,233, 1,255, 1,192, $1,169,1,148,1,064,992$, and 968 .

\section{2-(2-aminoethyl)-6-nitro-1H- benzo[de]isoquinoline-1,3(2H)-dione (3c)}

Tert-butyl (2-(6-nitro-1,3-dioxo-1H-benzo[de]isoquinolin2(3H)-yl)ethyl)carbamate $(1.02 \mathrm{~g}, 2.647 \mathrm{mMol}, 1 \mathrm{eq})$ was dissolved in (TFA: DCM, 50: 50) $(6 \mathrm{~mL})$ and was stirred at room temperature overnight. The solvent was removed under reduced pressure to yield a beige amorphous solid (0.70 g, 93\%). ${ }^{1} \mathrm{H}$ NMR, (DMSO-d $\left.6,500 \mathrm{MHz}\right) \delta(\mathrm{ppm}), J(\mathrm{~Hz}): 3.17$ (q, $J=$ $5.6,2 \mathrm{H}, \mathrm{CH}_{2}$ ), 4.33 (t, $J=5.6,2 \mathrm{H}, \mathrm{CH}_{2}$ ), 7.81 (br, $2 \mathrm{H}, \mathrm{NH}_{2}$ ), $8.13(\mathrm{~m}, 1 \mathrm{H}$, phenylene $\mathrm{H}), 8.58(\mathrm{~d}, J=7.9,1 \mathrm{H}$, phenylene $\mathrm{H})$, $8.66(\mathrm{~m}, 2 \mathrm{H}$, phenylene $\mathrm{H}), 8.76(\mathrm{dd}, 1 \mathrm{H}$, phenylene $\mathrm{H}) ;{ }^{13} \mathrm{C}$ NMR (DMSO-d $6,125 \mathrm{MHz}$ ): $\delta$ (ppm): 37.9, 38.2, 123.2, 123.4, 124.7, 127.2, 128.9, 129.4, 130.1, 130.6, 132.2, 149.7, 163.3, 164.0; HRMS (ESI) calcd. for $\mathrm{C}_{14} \mathrm{H}_{12} \mathrm{~N}_{3} \mathrm{O}_{4}[\mathrm{M}+\mathrm{H}]^{+}$286.082, found 286.0800; $v_{\max }(\mathrm{KBr}) / \mathrm{cm}^{-1}: 3,078,1,712,1,595,1,525,1,465$, $1,437,1,384,1,348,1,247,1,151,1,093,1,058,1,020$, and 981 .

\section{6-amino-2-(2-aminoethyl)-1H- benzo[de]isoquinoline-1,3(2H)-dione (3d)}

$\mathrm{Pd} / \mathrm{C}(\sim 0.2 \mathrm{~g})$ was added to a solution of 2-(2-aminoethyl)6-nitro-1H-benzo[de]isoquinoline-1,3(2H)-dione (1.00 g, 3.50 $\mathrm{mMol})$ dissolved in $\mathrm{MeOH}(40 \mathrm{~mL})$. The reaction was placed under a $\mathrm{H}_{2}$ atmosphere and left to stir at room temperature for $3 \mathrm{~h}$. The reaction was filtered through a pad of celite and washed with excess $\mathrm{MeOH}$, the filtrate was removed under reduced pressure to yield a mustard amorphous solid (0.673g, 75\%). ${ }^{\mathbf{1}} \mathbf{H}$ NMR, (DMSO- $\left.d_{6}, 500.13 \mathrm{MHz}\right) \delta(\mathrm{ppm}), J(\mathrm{~Hz}): 3.12(\mathrm{~s}, 2 \mathrm{H}$, $\left.\mathrm{CH}_{2}\right), 4.27\left(\mathrm{t}, J=6.0,2 \mathrm{H}, \mathrm{CH}_{2}\right), 6.86(\mathrm{~d}, J=8.4,1 \mathrm{H}$, phenylene $\mathrm{H}), 7.48\left(\mathrm{~s}, 2 \mathrm{H}, \mathrm{NH}_{2}\right), 7.67(\mathrm{~m}, 1 \mathrm{H}$, phenylene $\mathrm{H}), 7.77(\mathrm{br}$, $\left.2 \mathrm{H}, \mathrm{NH}_{2}\right), 8.21(\mathrm{~d}, \mathrm{~J}=8.4,1 \mathrm{H}$, phenylene $\mathrm{H}), 8.44(\mathrm{dd}, 1 \mathrm{H}$, phenylene $\mathrm{H}$ ), 8.63 (dd, $1 \mathrm{H}$, phenylene $\mathrm{H}$ ); ${ }^{13} \mathrm{C}$ NMR, (DMSO$\left.d_{6}, 125.76 \mathrm{MHz}\right) \delta(\mathrm{ppm}): 37.62,38.36,108.01,108.63,119.84$, $122.43,124.46,129.94,130.46,131.52,134.52,153.40,163.89$, 164.96; HRMS (ESI) calcd. for $\mathrm{C}_{14} \mathrm{H}_{14} \mathrm{~N}_{3} \mathrm{O}_{2}[\mathrm{M}+\mathrm{H}]^{+}$256.108, found 256.1055; $v_{\max }(\mathrm{KBr}) / \mathbf{c m}^{-1}: 3,419,3,362,3,259,3,017$, $1,636,1,582,1,531,1,485,1,429,1,402,1,378,1,353,1,311,1,247$, $1,203,1,172,1,128,1,016,964$, and 907 .

\section{6-((2-)((2-)((3,5- \\ Bis(Trifluoromethyl)Phenyl)Amino)-3,4- Dioxocyclobut-1-en-1- yl)Amino)Ethyl)Amino)-2-Ethyl-1H- Benzo[de]lsoquinoline-1,3-(2H)- Dione (SQ-1)}

A solution of 3-((3,5-bis(trifluoromethyl)phenyl)amino)4-ethoxycyclobut-3-ene-1,2-dione $(0.436 \mathrm{~g}, 1.235 \mathrm{mMol}$, 1 eq) in EtOH $(8 \mathrm{~mL})$ was added slowly to a mixture of 6-((2-aminoethyl)amino)-2-ethyl-1H-benzo[de]isoquinoline1,3(2H)-dione $(0.35 \mathrm{~g}, 1.235 \mathrm{mM}, 1 \mathrm{eq})$ and $\mathrm{Et}_{3} \mathrm{~N}(0.689 \mathrm{~mL}$, $4.94 \mathrm{mMol}, 4 \mathrm{eq})$ in EtOH $(12 \mathrm{~mL})$. The reaction was stirred at room temperature overnight. The precipitate was collected by suction filtration and washed with EtOH and ether. Product as a yellow amorphous solid with $78 \%$ yield $(0.575 \mathrm{~g}) .{ }^{1} \mathrm{H}$ NMR at $343 \mathrm{~K},\left(\mathrm{DMSO}-d_{6}, 500 \mathrm{MHz}\right) \delta(\mathrm{ppm}), J(\mathrm{~Hz}): 1.18(\mathrm{t}, J=$ 7.0, $3 \mathrm{H}, \mathrm{CH}_{3}$ ), 3.70 (q, $J=5.5,2 \mathrm{H}, \mathrm{CH}_{2}$ ), 3.95 (t, $J=5.5$, $\left.2 \mathrm{H}, \mathrm{CH}_{2}\right), 4.04\left(\mathrm{q}, J=7.0,2 \mathrm{H}, \mathrm{CH}_{2}\right), 6.91(\mathrm{~d}, J=8.5,1 \mathrm{H}$, phenylene $\mathrm{H}$ ), 7.47 (s, $1 \mathrm{H}$, phenylene $\mathrm{H}), 7.63$ ( $\mathrm{m}, 2 \mathrm{H}$, phenylene $\mathrm{H}), 7.80(\mathrm{br}, 2 \mathrm{H}, \mathrm{NH}), 7.89(\mathrm{~s}, 1 \mathrm{H}$, phenylene $\mathrm{H}), 8.25(\mathrm{~d}, J$ $=8.5,1 \mathrm{H}$, phenylene $\mathrm{H}), 8.39(\mathrm{~d}, \mathrm{~J}=7.0,1 \mathrm{H}$, phenylene $\mathrm{H})$, $8.58(\mathrm{~d}, J=8.3,1 \mathrm{H}$, phenylene $\mathrm{H}), 9.68(\mathrm{br}, 1 \mathrm{H}, \mathrm{NH}) ;{ }^{13} \mathrm{C}$ NMR at $343 \mathrm{~K},\left(\mathrm{DMSO}_{-} \mathrm{d}_{6}, 125.76 \mathrm{MHz}\right) \delta(\mathrm{ppm}): 13.6,30.9$, 34.6 , 43.2, 44.2, 104.6, 109.1, 114.7, 118.3, 120.8, 122.5, 124.7, $128.6,129.8,130.9,134.2,141.5,150.7,163.1,163.9,171.2,181.3$; HRMS (ESI) calcd. for $\mathrm{C}_{28} \mathrm{H}_{21} \mathrm{~F}_{6} \mathrm{~N}_{4} \mathrm{O}_{4}[\mathrm{M}+\mathrm{H}]^{+} 591.146$ found 591.1439; $\nu_{\max }(\mathrm{KBr}) / \mathrm{cm}-1: 3,292$ (broad), 3,086, 2,982, 1,796, 1,687, 1,581, 1,548, 1,459, 1,348, 1,278, 1,249, 1,180, 1,130, 1,067, 999 , and 932 .

\section{6-amino-2-(2-)((2-)((3,5- bis(trifluoromethyl)phenyl)amino)-3,4- dioxocyclobut-1-en-1-yl)amino)ethyl)-1H- benzo[de]isoquinoline-1,3(2H)-dione (SQ-2)} A solution of 3-((3,5-bis(trifluoromethyl)phenyl)amino)-4ethoxycyclobut-3-ene-1,2-dione $(0.14 \mathrm{~g}, \quad 0.39 \mathrm{mMol}, 1 \mathrm{eq})$ in $\mathrm{EtOH}(8 \mathrm{~mL})$ was slowly added to a mixture of 6 -amino2-(2-aminoethyl)-1H-benzo[de]isoquinoline-1,3(2H)-dione

$(0.1 \mathrm{~g}, 0.39 \mathrm{mmol}, 1 \mathrm{eq})$ and $\operatorname{Et} 3 \mathrm{~N}(0.217 \mathrm{~mL}, 1.56 \mathrm{mMol}$, $4 \mathrm{eq})$ in $\mathrm{EtOH}(10 \mathrm{~mL})$. The reaction was stirred at room temperature overnight. The precipitate was collected by suction filtration and washed with EtOH and Et2O to yield the product as an olive green amorphous solid $(0.123 \mathrm{~g}$, $56 \%) .{ }^{1} \mathrm{H} \mathrm{NMR}$ at $343 \mathrm{~K},\left(\mathrm{DMSO}_{-}, \mathrm{d}_{6}, 500.13 \mathrm{MHz}\right) \delta(\mathrm{ppm})$, $J(\mathrm{~Hz}): 3.90\left(\mathrm{~s}, 2 \mathrm{H}, \mathrm{CH}_{2}\right), 4.31\left(\mathrm{t}, J=6.0,2 \mathrm{H}, \mathrm{CH}_{2}\right), 6.82$ $(\mathrm{d}, J=8.4,1 \mathrm{H}$, phenylene $\mathrm{H}), 7.22\left(\mathrm{~s}, 2 \mathrm{H}, \mathrm{NH}_{2}\right), 7.52(\mathrm{~s}$, $1 \mathrm{H}$, phenylene $\mathrm{H}), 7.58(\mathrm{t}, J=8.0,1 \mathrm{H}$, phenylene $\mathrm{H}), 7.89$ (s, $2 \mathrm{H}$, phenylene $\mathrm{H}), 8.15(\mathrm{~d}, J=8.4,1 \mathrm{H}$, phenylene $\mathrm{H})$, $8.37(\mathrm{~d}, J=7.1,1 \mathrm{H}$, phenylene $\mathrm{H}), 8.57(\mathrm{~d}, J=8.4,1 \mathrm{H}$, phenylene $\mathrm{H}$ ), 9.77 (br, $1 \mathrm{H}, \mathrm{NH}) ;{ }^{13} \mathrm{C}$ NMR at $343 \mathrm{~K}$, (DMSO- $\mathrm{d}_{6}$, $125.76 \mathrm{MHz}) \delta(\mathrm{ppm}): 27.9,42.9,108.7,114.8,118.4,119.9$, $120.3,122.2,122.5,124.2,124.7,129.0,130.3,131.3,134.3$, $141.7,153.3,163.3,164.6,171.4,181.3$; HRMS (ESI) calcd. for $\mathrm{C}_{52} \mathrm{H}_{33} \mathrm{~F}_{12} \mathrm{~N}_{8} \mathrm{O}_{8}[2 \mathrm{M}+\mathrm{H}]^{+}$1125.223, found 1125.2226; $\nu_{\max }$ $(\mathrm{KBr}) / \mathrm{cm}^{-1}: 371,3,254,1,796,1,692,1,636,1,599,1,528,1,476$, $1,434,1,378,1,308,1,276,1,250,1,184,1,129,1,068,1,000$, and 933.

\section{DATA AVAILABILITY}

The datasets generated for this study are available on request to the corresponding author.

\section{AUTHOR CONTRIBUTIONS}

RE, LK, and MS designed the study and wrote the manuscript. RE and MS supervised the study. AA and LK synthesized and characterized the compounds and 
carried out all spectroscopic titrations. OF performed the SEM studies. MS, MK, and JP carried out the biological studies. All authors discussed the results and commented on the manuscript.

\section{ACKNOWLEDGMENTS}

LK wishes to acknowledge the Irish Research Council for a Government of Ireland Postdoctoral Research Fellowship (GOIPD/2017/1091). MK also acknowledges the Irish Research Council for a Government of Ireland Postgraduate Scholarship

\section{REFERENCES}

Adegoke, O., and Nyokong, T. (2013). Fluorescence "turn on" probe for bromide ion using nanoconjugates of glutathione-capped CdTe@ZnS quantum dots with nickel tetraamino-phthalocyanine: characterization and size-dependent properties. J. Photochem. Photobiol. A 265, 58-66. doi: 10.1016/j.jphotochem.2013.05.013

Amendola, V., Bergamaschi, G., Boiocchi, M., Fabbrizzi, L., and Milani, M. (2010). The squaramide versus urea contest for anion recognition. Chem. Eur. J. 16, 4368-4380. doi: 10.1002/chem.200903190

Andersen, O. S. (2013). "Cellular electrolyte metabolism," in Encyclopedia of Metalloproteins, eds R. H. Kretsinger, V. N. Uversky, and E. A. Permyakov (New York, NY: Springer New York), 580-587. doi: 10.1007/978-1-4614-1533-6_223

Ao, X., Bright, S. A., Taylor, N. C., and Elmes, R. B. P. (2017). 2-Nitroimidazole based fluorescent probes for nitroreductase; monitoring reductive stress in cellulo. Org. Biomol. Chem. 15, 6104-6108. doi: 10.1039/C7OB01406F

Ashton, T. D., Jolliffe, K. A., and Pfeffer, F. M. (2015). Luminescent probes for the bioimaging of small anionic species in vitro and in vivo. Chem. Soc. Rev. 44, 4547-4595. doi: 10.1039/C4CS00372A

Banerjee, S., Veale, E. B., Phelan, C. M., Murphy, S. A., Tocci, G. M., Gillespie, L. J., et al. (2013). Recent advances in the development of 1,8-naphthalimide based DNA targeting binders, anticancer and fluorescent cellular imaging agents. Chem. Soc. Rev. 42, 1601-1618. doi: 10.1039/c2cs35467e

Bao, X., Wu, X., Berry, S. N., Howe, E. N. W., Chang, Y.-T., and Gale, P. A. (2018). Fluorescent squaramides as anion receptors and transmembrane anion transporters. Chem. Commun. 54, 1363-1366. doi: 10.1039/C7CC08706C

Beer, P. D., and Gale, P. A. (2001). Anion recognition and sensing: the state of the art and future perspectives. Angew. Chem. Int. Ed., 40, 486-516. doi: 10.1002/ 1521-3773(20010202)40:3<486::AID-ANIE486>3.0.CO;2-P

Brynn Hibbert, D., and Thordarson, P. (2016). The death of the Job plot, transparency, open science and online tools, uncertainty estimation methods and other developments in supramolecular chemistry data analysis. Chem. Commun. 52, 12792-12805. doi: 10.1039/C6CC03888C

Busschaert, N., Caltagirone, C., Van Rossom, W., and Gale, P. A. (2015). Applications of supramolecular anion recognition. Chem. Rev. 115, 8038-8155. doi: 10.1021/acs.chemrev.5b00099

Busschaert, N., Elmes, R. B. P., Czech, D. D., Wu, X., Kirby, I. L., Peck, E. M., et al. (2014). Thiosquaramides: $\mathrm{pH}$ switchable anion transporters. Chem. Sci. 5, 3617-3626. doi: 10.1039/C4SC01629G

Busschaert, N., Kirby, I. L., Young, S., Coles, S. J., Horton, P. N., Light, M. E., et al. (2012). Squaramides as potent transmembrane anion transporters. Angew. Chem. Int. Ed. 51, 4426-4430. doi: 10.1002/anie.201200729

Calatrava-Pérez, E., Delente, J. M., Shanmugaraju, S., Hawes, C. S., Williams, C. D., Gunnlaugsson, T., et al. (2019). Glycosylated naphthalimides and naphthalimide Tröger's bases as fluorescent aggregation probes for Con A. Org. Biomol. Chem. 17, 2116-2125. doi: 10.1039/C8OB02980F

Cametti, M., and Rissanen, K. (2009). Recognition and sensing of fluoride anion. Chem. Commun. 2809-2829. doi: 10.1039/b902069a

Cametti, M., and Rissanen, K. (2013). Highlights on contemporary recognition and sensing of fluoride anion in solution and in the solid state. Chem. Soc. Rev. 42, 2016-2038. doi: 10.1039/C2CS35439J
(GOIPG/2015/3488). JP thanks Maynooth University for the award of a Hume Scholarship. Science Foundation Ireland are acknowledged for the funding of a Clariostar plate reader and Mass Spec facilities through the Opportunistic Infrastructure Fund (16/RI/3399).

\section{SUPPLEMENTARY MATERIAL}

The Supplementary Material for this article can be found online at: https://www.frontiersin.org/articles/10.3389/fchem. 2019.00354/full\#supplementary-material

de Silva, A. P., Gunaratne, H. Q. N., Gunnlaugsson, T., Huxley, A. J. M., McCoy, C. P., Rademacher, J. T., et al. (1997). Signaling recognition events with fluorescent sensors and switches. Chem. Rev. 97, 1515-1566.

Delgado-Pinar, E., Rotger, C., Costa, A., Pina, M. N., Jimenez, H. R., Alarcon, J., et al. (2012). Grafted squaramide monoamine nanoparticles as simple systems for sulfate recognition in pure water. Chem. Commun. 48, 2609-2611. doi: $10.1039 / \mathrm{c} 2 \mathrm{cc} 17798 \mathrm{f}$

Duke, R. M., Veale, E. B., Pfeffer, F. M., Kruger, P. E., and Gunnlaugsson, T. (2010). Colorimetric and fluorescent anion sensors: an overview of recent developments in the use of 1,8-naphthalimide-based chemosensors. Chem. Soc. Rev. 39, 3936-3953. doi: 10.1039/b910560n

Elmes, R. B. P., Busschaert, N., Czech, D. D., Gale, P. A., and Jolliffe, K. A. (2015). pH switchable anion transport by an oxothiosquaramide. Chem. Commun. 51, 10107-10110. doi: 10.1039/C5CC03625A

Elmes, R. B. P., Erby, M., Bright, S. A., Williams, D. C., and Gunnlaugsson, T. (2012). Photophysical and biological investigation of novel luminescent $\mathrm{Ru}(\mathrm{ii})$ polypyridyl-1,8-naphthalimide Tröger's bases as cellular imaging agents. Chem. Commun. 48, 2588-2590. doi: 10.1039/c2cc17274g

Elmes, R. B. P., and Gunnlaugsson, T. (2010). Luminescence anion sensing via modulation of MLCT emission from a naphthalimide-Ru(II)-polypyridyl complex. Tet. Lett. 51, 4082-4087. doi: 10.1016/j.tetlet.2010.05.127

Elmes, R. B. P., and Jolliffe, K. A. (2014). Amino acid-based squaramides for anion recognition. Supramol. Chem. 27, 321-328. doi: 10.1080/10610278.2014. 976221

Elmes, R. B. P., Turner, P., and Jolliffe, K. A. (2013). Colorimetric and luminescent sensors for chloride: hydrogen bonding vs deprotonation. Org. Lett. 15, 5638-5641. doi: 10.1021/ol402500q

Elmes, R. B. P., Yuen, K. K. Y., and Jolliffe, K. A. (2014). Sulfate-selective recognition by using neutral dipeptide anion receptors in aqueous solution. Chem. Eur. J. 20, 7373-7380. doi: 10.1002/chem.201400292

Evans, N. H., and Beer, P. D. (2014). Advances in anion supramolecular chemistry: from recognition to chemical applications. Angew. Chem. Int. Ed. 53, 11716-11754. doi: 10.1002/anie.201309937

Fan, J., Hu, M., Zhan, P., and Peng, X. (2013). Energy transfer cassettes based on organic fluorophores: construction and applications in ratiometric sensing. Chem. Soc. Rev. 42, 29-43. doi: 10.1039/C2CS35273G

Gale, P. A., and Howe, E. N. W., Wu, X. (2016). Anion receptor chemistry. Chemistry 1, 351-422. doi: 10.1016/j.chempr.2016.08.004

Gribble, G. W. (2004). Amazing organohalogens: although best known as synthetic toxicants, thousands of halogen compounds are, in fact, part of our natural enviornment. Am. Sci. 92, 342-349. doi: 10.1511/2004. 48.937

Gunnlaugsson, T., Glynn, M., Tocci, G. M., Kruger, P. E., and Pfeffer, F. M. (2006). Anion recognition and sensing in organic and aqueous media using luminescent and colorimetric sensors. Coord. Chem. Rev. 250, 3094-3117. doi: 10.1016/j.ccr.2006.08.017

Hoizey, G., Lamiable, D., Millart, H., and Trenque, T. (2003). Bromism from daily over intake of bromide salt AU - Frances, C. J. Toxicol. 41, 181-183. doi: 10.1081/CLT-120019135

Hong, Y., Lam, J. W. Y., and Tang, B. Z. (2011). Aggregation-induced emission. Chem. Soc. Rev. 40, 5361-5388. doi: 10.1039/c1cs15113d 
Jin, C., Zhang, M., Wu, L., Guan, Y., Pan, Y., Jiang, J., et al. (2013). Squaramidebased tripodal receptors for selective recognition of sulfate anion. Chem. Commun. 49, 2025-2027. doi: 10.1039/c3cc00196b

Kang, J., and Kim, J. (2005). Bromide selective fluorescent anion receptor with glycoluril molecular scaffold. Tet. Lett. 46, 1759-1762. doi: 10.1016/j.tetlet.2004.09.065

Kumar, M., Kumawat, L. K., Gupta, , V. K., and Sharma, A. (2016). Novel furochromenone based dual channel sensors for selective detection of $\mathrm{Cu} 2+$ with potential applications in sample monitoring, membrane sensing and photo-printing. Chem. Select 1, 277-284. doi: 10.1002/slct.2015 00023

Kumawat, L. K., Asif, M., and Gupta, V. K. (2017). Dual ion selective fluorescence sensor with potential applications in sample monitoring and membrane sensing. Sens. Actuators B. Chem. 241, 1090-1098. doi: 10.1016/j.snb.2016.10.031

Langton, M. J., Serpell, C. J., and Beer, P. D. (2016). Anion recognition in water: recent advances from a supramolecular and macromolecular perspective. Angew. Chem. Int. Ed. 55, 1974-1987. doi: 10.1002/anie.201506589

Lee, M. H., Kim, J. S., and Sessler, J. L. (2015). Small molecule-based ratiometric fluorescence probes for cations, anions, and biomolecules. Chem. Soc. Rev. 44, 4185-4191. doi: 10.1039/C4CS00280F

Lim, J. Y. C., and Beer, P. D. (2019). Electrochemical bromide sensing with a halogen bonding [2]Rotaxane. Eur. J. Org. Chem. doi: 10.1002/ejoc.201801571. [Epub ahead of print].

Lowe, A. J., Pfeffer, F. M., and Thordarson, P. (2012). Determining binding constants from $1 \mathrm{H}$ NMR titration data using global and local methods: a case study using [n]polynorbornane-based anion hosts. Supramol. Chem. 24, 585-594. doi: 10.1080/10610278.2012.688972

Ma, H., Yang, M., Zhang, S., Yin, P., Wang, T., Yang, Y., et al. (2019). Two aggregation-induced emission (AIE)-active reaction-type probes: for realtime detecting and imaging of superoxide anions. Analyst 144, 536-542. doi: 10.1039/C8AN01811A

Marchetti, L. A., Mao, N., Krämer, T., Kitchen, J. A., and Elmes, R. B. P. (2018). A long wavelength colourimetric chemosensor for fluoride. Supramol. Chem. 30, 795-805. doi: 10.1080/10610278.2018.1461873

Marcus, Y. (1991). Thermodynamics of solvation of ions. Part 5.-Gibbs free energy of hydration at 298.15 K. J. Chem. Soc. Faraday Transac. 87, 2995-2999.

Olson, K. R., and System, C. P. C. (2004). Poisoning and Drug Overdose; Lange Medical. New York, NY: Books/McGraw-Hill.

Peng, L., Wang, M., Zhang, G., Zhang, D., and Zhu, D. (2009). A fluorescence turnon detection of cyanide in aqueous solution based on the aggregation-induced emission. Org. Lett. 11, 1943-1946. doi: 10.1021/ol900376r

Piña, M. N., Soberats, B., Rotger, C., Ballester, P., Deyà, P. M., and Costa, A. (2008). Selective sensing of competitive anions by non-selective hosts: the case of sulfate and phosphate in water. New J. Chem. 32, 1919-1923. doi: 10.1039/b809454c

Prohens, R., Martorell, G., Ballester, P., and Costa, A. (2001). A squaramide fluorescent ensemble for monitoring sulfate in water. Chem. Commun. 1456-1457. doi: 10.1039/b104172j

Prohens, R., Tomàs, S., Morey, J., Deyà, P. M., Ballester, P., and Costa, A. (1998). Squaramido-based receptors: Molecular recognition of carboxylate anions in highly competitive media. Tet. Lett. 39, 1063-1066. doi: 10.1016/S0040-4039(97)10728-6

Qin, L., Hartley, A., Turner, P., Elmes, R. B. P., and Jolliffe, K. A. (2016). Macrocyclic squaramides: anion receptors with high sulfate binding affinity and selectivity in aqueous media. Chem. Sci. 7, 4563-4572. doi: 10.1039/C6SC01011C

Ryan, G. J., Elmes, R. B. P., Quinn, S. J., and Gunnlaugsson, T. (2012). Synthesis and photophysical evaluations of fluorescent quaternary bipyridyl- 1,8-naphthalimide conjugates as nucleic acid targeting agents. Supramol. Chem 22, 175-188. doi: 10.1080/10610278.2011.638381

Ryan, G. J., Poynton, F. E., Elmes, R. B. P., Erby, M., Williams, D. C., Quinn, S. J., et al. (2015). Unexpected DNA binding properties with correlated downstream biological applications in mono vs. bis-1,8-naphthalimide Ru(ii)-polypyridyl conjugates. Dalton Trans. 44, 16332-16344. doi: 10.1039/C5DT00360A

Sedgwick, A. C., Wu, L., Han, H.-H., Bull, S. D., He, X.-P., James, T. D., et al. (2018). Excited-state intramolecular proton-transfer (ESIPT) based fluorescence sensors and imaging agents. Chem. Soc. Rev. 47, 8842-8880. doi: 10.1039/C8CS00185E

Storer, R. I., Aciro, C., and Jones, L. H. (2011). Squaramides: physical properties, synthesis and applications. Chem. Soc. Rev. 40, 2330-2346. doi: $10.1039 / \mathrm{c} 0 \mathrm{cs} 00200 \mathrm{c}$

Suksai, C., Leeladee, P., Jainuknan, D., Tuntulani, T., Muangsin, N., Chailapakul, O., et al. (2005). A new heteroditopic receptor and sensor highly selective for bromide in the presence of a bound cation. Tet. Lett. 46, 2765-2769. doi: 10.1016/j.tetlet.2005.02.156

Thordarson, P. (2011). Determining association constants from titration experiments in supramolecular chemistry. Chem. Soc. Rev. 40, 1305-1323. doi: 10.1039/C0CS00062K

Verkman, A. S. (1990). Development and biological applications of chloridesensitive fluorescent indicators. Am. J. Physiol. Cell Physiol. 259, C375-C388. doi: 10.1152/ajpcell.1990.259.3.C375

Vlascici, D., Plesu, N., Fagadar-Cosma, G., Lascu, A., Petric, M., Crisan, M., et al. (2018). Potentiometric sensors for iodide and bromide based on $\mathrm{Pt}(\mathrm{II}$ ) Porphyrin. Sensors 18:E2297. doi: 10.3390/s18072297

World Health Organization (2005). Bromate in Drinking-Water: Background Document for Development of WHO Guidelines for Drinking-Water Quality. Geneva.

World Health Organization (2009). Bromide in Drinking-Water: Background Document for Development of WHO Guidelines for Drinking-Water Quality. Geneva.

Wu, D., Cheung, S., Sampedro, G., Chen, Z.-L., Cahill, R. A., and O'Shea, D. F. (2018). A DIE responsive NIR-fluorescent cell membrane probe. Biochim. Biophys. Acta 1860, 2272-2280. doi: 10.1016/j.bbamem.2018.09.006

Wu, J., Liu, W., Ge, J., Zhang, H., and Wang, P. (2011). New sensing mechanisms for design of fluorescent chemosensors emerging in recent years. Chem. Soc. Rev. 40, 3483-3495. doi: 10.1039/c0cs00224k

Wurm, F. R., and Klok, H.-A. (2013). Be squared: expanding the horizon of squaric acid-mediated conjugations. Chem. Soc. Rev. 42, 8220-8236. doi: 10.1039/c3cs60153f

Xu, L., Xu, Y., Zhu, W., Xu, Z., Chen, M., and Qian, X. (2012). Fluorescence sensing of iodide and bromide in aqueous solution: anion ligand exchanging and metal ion removing. New J. Chem. 36, 1435-1438. doi: 10.1039/c2nj40102a

Zhai, D., Xu, W., Zhang, L., and Chang, Y.-T. (2014). The role of "disaggregation" in optical probe development. Chem. Soc. Rev. 43, 2402-2411. doi: $10.1039 /$ c3cs60368g

Conflict of Interest Statement: The authors declare that the research was conducted in the absence of any commercial or financial relationships that could be construed as a potential conflict of interest.

Copyright (c) 2019 Kumawat, Abogunrin, Kickham, Pardeshi, Fenelon, Schroeder and Elmes. This is an open-access article distributed under the terms of the Creative Commons Attribution License (CC BY). The use, distribution or reproduction in other forums is permitted, provided the original author(s) and the copyright owner(s) are credited and that the original publication in this journal is cited, in accordance with accepted academic practice. No use, distribution or reproduction is permitted which does not comply with these terms. 